Eskişehir Osmangazi Üniversitesi Iïß Dergisi

Aralık 2020, C. 15, S. 3, 1019- 1042

Başvuru : 09.03.2019

Kabul : :01.04.2020

\title{
Kaynak Temelli Görüş Ekseninde Örgütsel Kaynakların Rekabet Stratejileri Üzerindeki Etkisi: Türkiye'nin İlk 1000 Büyük Sanayi Kuruluşu'nda Bir Araştırma ${ }^{1}$
}

\author{
Burak Özdemir ${ }^{2}$ \\ Deniz Taşci ${ }^{3}$
}

Kaynak Temelli Görüş Ekseninde Örgütsel Kaynakların Rekabet Stratejileri Üzerindeki Etkisi: Türkiye'nin ilk 1000 Büyük Sanayi Kuruluşu'nda Bir Araştırma

Öz

$\mathrm{Bu}$ araştırmanın amacı, kaynak temelli görüş ekseninde firmaların sahip olduğu örgütsel kaynakların rekabet stratejileri üzerindeki etkisini ortaya koymaktır. Bunun yanı sıra, firmaların faaliyet gösterdiği sektörün teknolojik sınıflamasına ve firmaların ortaklık yapısına göre örgütsel kaynaklarının ve rekabet stratejilerinin farklılaşıp farklılaşmadığı incelenmiştir. İstanbul Sanayi Odası (iSO) tarafından belirlenen Türkiye'nin ilk 1000 büyük sanayi firması araştırmanın evrenini oluşturmaktadır ve firmalardan tam sayım yöntemi ile veriler elde edilmiştir. Araştırmadan elde edilen ilk bulgu, yapısal sermayenin farklılaşma stratejisini pozitif etkilediğidir. Ayrıca, ortaklık yapısına göre sosyal sermaye; faaliyet gösterilen sektörün teknolojik sınıflamasına göre farklılaşma stratejisi ve sosyal sermayenin anlamlı şekilde farklılaştığı belirlenmiştir.

Anahtar Kelimeler: Kaynak Temelli Görüş, Rekabet Stratejileri, Örgütsel Kaynaklar, ISO birinci 500, ISO ikinci 500
The Impact of Organizational Resources on Competitive Strategies within the Scope of Resource Based View: A Research in Top 1000 Industrial Enterprises of Turkey

Abstract

The purpose of this study is to investigate the effects of organizational resources on competitive strategies in resource-based view context. In addition, according to technological classification of the industry and the ownership structure of the firms, it is examined whether their organizational resources and competitive strategies differ. Turkey's first 1000 major industrial firm specified by Istanbul Chamber of Industry (ICI) determined as population of study and data obtained from those firms by full counting method. The first finding from this research is that structural capital affects the differentiation strategy positively. Besides, firms' social capital varies up to firm's ownership structure. Furthermore, differentiation strategy and social capital of firms differ significantly with regards to technological classification of the industry.

Keywords: Resource Based View, Competitive Strategies, Organizational Resources, ICI I. 500, ICI II. 500

\section{Giriş}

Yoğun rekabet koşulları altında acımasızca son bulan örgütsel hayatlar düşünüldüğünde bazı firmaların neden diğerlerine göre daha başarılı olduğu ve ne şekilde sürdürülebilir rekabet avantajını elde ettiği (Teece vd., 1997: 509) önemli bir tartışma konusudur. Stratejik yönetim yazını bu bağlamda iki temel içerik okuluna vurgu yapmaktadır (Barca, 2017). Bunlardan biri dış faktör paradigması çerçevesinde değerlendirilen pozisyon okulu ve diğeri iç faktör paradigması kapsamında bilgiler sunan kaynak temelli görüş (KTG) yaklaşımıdır (Chakravarthy ve Doz, 1992: 6; Montgomery vd., 1989:192). KTG, sürdürülebilir rekabet avantajı ve firmalar için uzun yaşamın

\footnotetext{
${ }^{1}$ Bu çalışma Eskişehir Osmangazi Üniversitesi Sosyal Bilimler Enstitüsü İşletme Anabilim Dalı’nda Prof. Dr. Deniz Taşcı danışmanlığında Burak Özdemir tarafından “Örgütsel Yapı ve Kaynak Temelli Görüş Kapsamında Örgütlerde Rekabet Stratejileri: Türkiye'nin İlk 1000 Sanayi Kuruluşu'nda Bir Araştırma” ismiyle tamamlanarak 22.12.2016 tarihinde savunulan doktora tezinden türetilmiştir. Değerli görüş, öneri ve eleştirileri için çalışmanın anonim iki hakemine ve editöryel katkı ve destekleri için dergi editörlüğüne teşekkürlerimizi sunarız.

2 Dr. Öğr. Üyesi, Kastamonu Üniversitesi iiBF, bozdemir@kastamonu.edu.tr, Yazar ORCID bilgisi: http://orcid.org/00000002-2710-4112.

3 Prof. Dr., Anadolu Üniversitesi, İletişim Bilimleri Fakültesi, dtasci@gmail.com, Yazar ORCID bilgisi: http://orcid.org/0000-0002-1345-0751.
} 
sırlarını pozisyon okulunun aksine dışsal faktörlerden ziyade içsel faktörleri dikkate alarak firmaların değerli, nadir, ikame edilemez ve taklit edilemez kaynaklarına ve bu kaynakların firmalar arasındaki heterojen dağılımına bağlamaktadır (Peteraf, 1993; Wernerfelt, 1984; Barney ve Hesterly, 1999).

Bu araştırma örgütsel kaynakların örgütün rekabet stratejileri ile olan ilişkisini KTG çerçevesinde incelemektedir. Örgütsel kaynaklar maddi kaynaklar ve maddi olmayan kaynaklar olarak ayrı ayrı incelenmiştir. Maddi kaynakların belirlenmesinde örgütlerin aktiflerinden yararlanılırken maddi olmayan kaynakların incelenmesinde entelektüel sermayeden faydalanılmıştır. Araştırmada örgüt stratejileri iki iş düzey stratejisi bağlamında; maliyet liderliği ve farklılaşma stratejisi olarak ele alınmıştır. İş düzey stratejiler, stratejik formülasyon (strateji oluşturma) safhasında stratejik yönetim sürecinin önemli bir parçasıdır. İş düzey stratejiler ile firma, rakiplerinden farklı olarak müşteriler tarafından değer gören ürün ve hizmetleri üretmek (farklılaşma stratejisi) ya da düşük fiyata mal edilen standart ürün ve hizmetler sunmak yoluyla (maliyet liderliği stratejisi) rekabet avantajı elde etmeyi amaçlamaktadır (Porter, 1980). En nihayetinde benimsenen ve oluşturulan iş düzey stratejinin firma kaynaklarıyla yakından ilişkili olduğu ve firma kaynakları doğrultusunda belirlenmesi gerektiği bilinmektedir (Grant, 1991: 114; Bharadwaj, 1994: 87; Lopez-Cabarcoz vd., 2015: 3). Ancak alanyazın incelendiğinde örgütsel kaynakların bu araştırmada yer alan şekliyle maliyet liderliği stratejisi ve farklılaşma stratejisi üzerindeki etkisinin araştırmalara yeterince konu olmadığı görülmektedir. Bu doğrultuda araştırmada örgütün maddi kaynaklarının maliyet liderliği stratejisini (Grant, 1991; Kaleka, 2002) ve maddi olmayan kaynaklarının diğer bir ifade ile entelektüel sermayenin de farklılaştırma stratejisini (Walsh, 2008; Adedoyin ve Ezenwakelu, 2019) yordadığı öne sürülmektedir. Ayrıca Türkiye bağlamında en çok üretimden satış yapan firmaların örgütsel kaynaklar ve rekabet stratejilerine yaklaşımı, firmaların ortaklık yapıları ve faaliyet gösterdikleri sektörlerin teknolojik sınıflaması çerçevesinde merak uyandırıcı niteliktedir.

\section{Kavramsal Çerçeve}

\subsection{Kaynak Temelli Görüş ve Kaynaklar}

KTG'nin yükselişi 1984 yılı ve 1990'lı yılların ortaları itibari ile gerçeklemiştir (Kraaijenbrink vd., 2010: 351). 1994 yılında Stratejik Yönetim Topluluğu (Strategic Management Society) tarafından Wernerfelt'in 1984 yılındaki makalesi "A Resource-Based View of the Firm" en etkili araştırma olarak seçilmiştir (Wernerfelt, 1995). Bu doğrultuda Wernerfelt (1984), Rumelt (1984), Barney $(1986,1991)$ ve Dierickx ve Cool (1989) başını çektiği çalışmalar doğrultusunda KTG'nin stratejik yönetim alanındaki gelişimi dikkat çekmeye başlamıştır (Priem ve Butler, 2001: 23). KTG rekabet üstünlüğünün anlaşılmasında ön plana çıkmaktadır (Powell, 2001: 881). KTG'nin yönetim bilimi teorileri içerisinde söz sahibi olduğu (Kraaijenbrink vd., 2010: 350); stratejik yönetim alanındaki etkileyiciliği (Barney vd., 2001: 625) ve dikkat çekici duruşu ile (Lo, 2012: 151) rekabet üstünlüğünün yaratılması ve sürdürülmesinde tatmin edicilikten uzak geleneksel stratejik yönetim araçlarına tepki niteliğinde geliştiği (Ford ve Mahieu, 1998: 1) ifade edilebilir. KTG, örgütlerin kaynaklarına ve kabiliyetlerine dayalı iki temel varsayımı içermektedir. Birincisine göre kaynaklar ve kabiliyetler örgütler arasında heterojen bir dağılım göstermektedir. İkinci olarak bu dağılım transfer edilemezdir ve KTG'nin özünü betimlemektedir (Barney ve Hesterly, 1999). KTG, sürdürülebilir rekabet avantajının sağlanmasında örgütün kontrol ettiği tüm değerli, nadir olan, taklit ve ikame edilemez kaynakların ve kabiliyetlerin rol oynadığını vurgulamaktadır (Peteraf, 1993; Barney vd., 2001). Barney'e (1991: 106) göre firma kaynakları eğer sürdürülebilir rekabet avantajının bir kaynağı olarak firma etkinlik ve verimliliğini arttıran firma 
stratejilerinin kurulması ve uygulanmasına olanak yaratıyorsa ancak o zaman değerlidir. Kabue ve Kilika (2016: 101) firma kaynaklarının değerli olmasının yanı sıra ikinci önemli özelliğin kaynağın nadir olması olduğunu belirtmiştir. Nadir olan kaynak rakipler tarafından kullanılmamalı ve değerinden uzaklaşmamalıdır. Nadir olan kaynağın arzı, talebinden daha az olmalıdır (Hoopes vd., 2003). Stratejik kaynakların önemli bir diğer özelliği taklit edilemezliktir. Örgütsel kaynakların taklit edilemezliğini güçlendiren üç etmen vardır. Bunlar, kaynağı elde etme becerisinin eşsiz tarihsel koşullara bağlı olması, sahip olunan kaynaklar ve sürdürülebilir rekabet avantajı ilişkisi arasındaki nedenselliğin belirsiz olması ve örgüte üstünlük sağlayan kaynakların sosyal karmaşıklık içermesidir (Dierickx ve Cool, 1989). Rekabet üstünlüğü sağlayan kaynakların son özelliği ise ikame edilemez olmasıdır. Micheal Porter beş güç faktör yaklaşımını ileri sürdüğünden beri benzersiz bir kaynak acaba başka bir kaynak tarafından ikame edilebilir mi sorusunun cevabı tüm stratejistlerin merak ettiği bir konudur. Örnek vermek gerekirse çelik üreticileri sektörü ana pazarlardan biri olan içecek kutusu pazarını alüminyum üreticilerine kaptırmıştır. KTG ile ilgi, firmanın ürün ve hizmet yaratma becerisindeki kaynakların düzeyine yönelmiştir (Collis ve Montgomery, 1995: 120). İkame edilebilirlik iki farklı açıdan ele alınmaktadır. İlkinde, bir firma başka bir firmanın kaynaklarını tam olarak taklit edemiyorsa aynı stratejiyi düşünmeye ve uygulamaya olanak tanıyan benzer bir kaynağı ikame edebilir görüşü söz konusudur. Örneğin, rakip firmanın yüksek kalitedeki üst yönetimini kopyalamak pek olası değildir. Bunun yerine onu ikame edecek kendine ait bir üst yönetim ekibi oluşturulabilir. İkincisinde ise birbirine benzemeyen çok farklı türdeki firma kaynakları birbirinin ikamesi olarak değerlendirilebilir. Örneğin, bir firmanın karizmatik bir lidere sahip olması nedeniyle o firmanın yöneticileri firmalarının geleceği hakkında net vizyon sahibi olabilir. Benzer şekilde rekabet eden firmaların yöneticileri de firmalarının geleceği ile ilgili net bir vizyon sahibi olabilir. Ancak onların bu vizyona sahip olmalarının sebebi karizmatik bir liderden ziyade formel bir planlama sistemi uygulamalarıdır (Barney ve Clark, 2007: 66).

Foss ve Robertson (2005: 2) "kaynaklar", "yetkinlikler", "kabiliyetler", vb. kavramları terimsel bir karmaşa yarattığını ve aslında tüm bu kavramların "stratejik varlıklar" olarak nitelendirilebileceğini belirtmektedir. Barney'e (1991: 3) göre kabiliyetler, örgütsel süreçler, firma yetenekleri, bilgi, beceri ve benzeri firma tarafından kontrol edilen firmanın verimlilik ve etkinliğini geliştirici firma stratejilerini oluşturma ve kurma imkânı sağlayan tüm varlıklar aslında örgütsel kaynakları oluşturmaktadır. Bu araştırmada araştırmanın amacı doğrultusunda örgütsel kaynaklar, maddi kaynaklar ve maddi olmayan kaynaklar olarak sınıflandırılmıştır. KTG çerçevesinde maddi kaynaklar; fiziksel ve finansal kaynaklar olarak ele alınmıştır (Grant, 1991: 119; Kostopoulos vd., 2002: 4). Maddi olmayan kaynaklar ise entelektüel sermaye olarak (Kristandl ve Bontis, 2007; Cater ve Cater, 2009) incelenmiştir.

Maddi kaynakları tanımlanması ve değerlemesi oldukça basittir. Firma bilançosundaki fiziksel (demirbaşlar, makinalar, arsa, maden rezervleri) ve finansal (nakit değer, borçlanma kapasitesi, tahviller) kaynaklardan oluşmaktadır (Grant, 2013: 118-119). Maddi olmayan kaynaklar örgütün fiziksel ve finansal yapıda olmayan tüm kaynakları olarak belirtilebilir (Lev, 2001). Firmalar açısından maddi olmayan kaynaklar, maddi kaynakların önüne geçmiş vaziyettedir (Görmüş, 2009: 58). Maddi olmayan kaynaklar örgütsel, ilişkisel, teknolojik ve insan temelli sermayeden oluşmaktadır (Fernandez vd., 2000; Lev, 2001; Seppanen, 2009). Esasen maddi olmayan kaynaklar entelektüel sermaye şeklinde nitelendirilmektedir (Choong, 2008: 609). Günümüzde firmaların değerini sadece fiziksel ve finansal kaynaklar değil maddi olmayan entelektüel kaynaklar da yansıtmaktadır (Yıldız, 2011: 12). Entelektüel sermaye firmaların uzun vadeli hedeflerini 
gerçekleştirmesine yardımcı olan stratejik varlıklar olarak ifade edilmektedir (Yereli ve Gerşil, 2005: 28). Entelektüel sermayeye ilişkin farklı sınıflandırmalar bulunmakla beraber özellikle müşteri sermayesi yerine ilişkisel sermaye ve yapısal sermaye yerine örgütsel sermayenin kullanıldığı görülmektedir (Daou vd., 2013: 1674-1675). Entelektüel sermaye kavramı maddi olmayan kaynaklar bağlamında insan sermayesi, yapısal (örgütsel) sermaye ve ilişkisel (müşteri) sermaye alt kategorilerinde incelenmektedir (Choong, 2008: 632; Sanchez vd., 2000). Bu araştırmada Subramaniam ve Youndt'un (2005) entellektüel sermayeye ilişkin belirttiği insan sermayesi, örgütsel sermaye (yapısal sermaye) ve sosyal sermaye alt boyutları esas alınmıştır. İnsan sermayesi çalışanların; beceri, kabiliyet, deneyim, problem çözme yetenekleri, yönetim tarzı yetenekleri ve işgücü bilgisi (Brooking, 1996), bireysel bilgi düzeyleri (Bontis vd., 1999), kabiliyet, tatmin ve süreklilikleri (Moon ve Kym, 2006), eğitim, yetkinlik ve girişimcilikleri (Sveiby, 1997), motivasyon, sorumluluk, potansiyel ve kabiliyetleri (Andrikopoulos, 2010) şeklindeki somut ve soyut nitelikler (Tokgöz vd., 2020: 51) olarak ifade edilmektedir. Sosyal sermaye ilişkisel bir kaynak olarak (Tsai ve Ghoshal, 1998: 464) örgütün içinde yerleşik bulunduğu topluluğun aynı zamanda bir sermaye kaynağı olduğunu öne sürmektedir (Kittikunchotiwut, 2015: 3). Baron ve Armstrong (2007: 14) yapısal sermayeyi bilgi teknolojileri yardımıyla hazırda erişilebilen ve örtük olmaktan çıkıp kolayca veri tabanlarına yayılabilen bilgi (kişide saklı kalmayarak yerel ağ, hiper metin, hiper medya, hiper bağlantı, veri madenciliği gibi teknolojiler aracılığında açığa çıkarılan, paylaşılan ve kodlanan bilgi) veya kurumsallaşmış bilgi (kılavuzlarda veya standart işletim prosedürlerinde yer alan açık bilgi) şeklinde tanımlamaktadır. Yapısal sermaye kurumsallaşmış bilgi ve yapı, sistem, süreç, talimat, patentler ile veri tabanlarından oluşan yazılı edinimleri içermektedir (Subramaniam ve Youndt, 2005: 451). Meyer vd. (2014: 326) entelektüel sermayenin diğer iki bileşeninin (insan sermayesi ve sosyal sermaye) örgüt çalışanlarına bağımlı olduğunu yapısal sermayenin ise örgüt seviyesinde elde edilen bir bilgi olduğunu belirtmektedir.

\subsection{Rekabet Stratejileri}

Firmalar için rekabet avantajı elde etmenin tek başına yeterli olmadığı, esas olanın rekabet avantajının sürdürülebilir nitelikte olması gerektiği bilinmektedir. Sürdürülebilir rekabet avantajını elde edebilmek için ise firmaların kullanabileceği en önemli araçlardan biri rekabet stratejileridir (Alayoğlu, 2010: 30). Rekabet stratejileri ile firma, faaliyet gösterdiği sektörde kendisini rekabetçi diğer güçlere karşı en iyi savunabileceği bir pozisyona konumlandırmayı amaçlamaktadır (Akbolat ve Işık, 2012: 402). Porter (1985) sürdürülebilir rekabet avantajının elde edilmesi için örgütlerin uygulayabileceği üç jenerik strateji ileri sürmüştür. Bunlar maliyet liderliği, farklılaşma ve odaklanma stratejileridir. Aslında odaklanma stratejisi de maliyet liderliğine odaklanma ve farklılaşmaya odaklanma olarak ikiye ayrılmaktadır. Odaklanma stratejisi örgütün hedeflediği pazarın kapsamı ile ilgilidir. Örgütün faaliyet gösterdiği pazarın kapsamı ister geniş ister dar olsun temelde uyguladığı stratejiler özünde maliyet liderliği ve farklılaşmaya dayanmaktadır. Araştırma bu doğrultuda rekabet stratejilerini incelerken maliyet liderliği ve farklılaşma stratejilerini esas almıştır.

Verimlilik avantajına göre birçok sektörde tipik olarak yüksek satış miktarlarına ve maliyet liderliğine sahip olan firmalar ile onları takip eden rakipleri bulunmaktadır (Gümüş, 2009: 108). Maliyet lideri firmalar maliyet denetimi ile ortalamanın üzerinde getiri elde etmeyi amaçlamaktadır (Hsieh ve Chen, 2011: 14). Rakiplerine göre maliyetlerini düşürmenin yollarını bulmaya odaklanarak hedef pazardan daha büyük pay elde etmek hedefindedirler. Maliyet liderliği stra- 
tejisi ile firmalar pazarın ortalama müşterilerine standart ürünleri satmaktadır. Zaten bu müşteri grubu da genellikle pazarın en büyük kesimini oluşturmaktadır (Hitt vd., 2009: 106). Porter'a göre (1985: 13-14) firmalar için maliyet liderliği stratejisinde olması gereken maliyet lideri pozisyonu için mücadele eden firmalardan biri değil doğrudan maliyet lideri olmaktır. Bu gerçeği kavrayamayan firmalar stratejik hatalarla karşı karşıya kalmaktadır. Maliyet lideri olmak için birden çok firma çetin bir rekabet içerisindedir. Ne zaman ki bu firmalardan biri diğerlerinin vazgeçişini izler ve maliyet lideri olur, işte o zaman muazzam bir kârında sahibi olur.

Endüstrisine marka imajı, ürün özellikleri, müşteri hizmetleri ve bayi ağı ile benzersiz bir ürün ya da hizmet algısı sunan bir firma, farklılaşma stratejisini izleyerek avantaj sahibi olmayı tasarlamaktadır (Segev, 1989: 501). Başarılı bir farklılaşma stratejisinde müşteri, firmanın benzersiz ürün veya hizmetine çok daha fazla bedel ödemek için isteklidir. Farklılaşma stratejisinin yüksek performansa öncülük etmesi müşterinin ürün veya hizmeti benzersiz yapan özelliklere, ona bedelini ödeyecek kadar değer vermesi ya da ilgili firmayı seçmesi doğrultusunda gerçekleşmektedir (Harrison ve John, 2010: 90). Farklılaşma stratejisi ile müşteri sadakatini elde etmek ve yüksek fiyatlı ürün veya hizmetler için talep oluşturmak amaçlanmaktadır (Pearce ve Robinson, 2015: 185).

\subsection{Kaynak Temelli Görüş Ekseninde Örgütsel Kaynakların Rekabet Stratejilerine Etkisi}

Stratejik yönetim düşüncesinin gelişimi stratejik planlama anlayışı dönemi (1960-1980), rekabet strateji anlayışı dönemi (1980-1990) ve kaynak ve kabiliyetlere dayalı strateji anlayışı dönemi (1990'dan günümüz) olmak üzere üç ana dönemden oluşmaktadır. 1960'ların başında ortaya çıkan ilk dönem, geleneksel bir mantıksal çıkarım ile amaçlar ve araçlar arasında planlamacı bir ilişki öne sürmüştür. 1980'li yıllarda pozisyon okulu olarak da bilinen rekabetçi stratejiler döneminde endüstrideki beş temel güce karşı firmanın kendini savunabilmesi adına pazar pozisyonunu geliştirmesi vurgulanmıştır. Üçüncü dönemde ise KTG yükselişe geçerek örgütsel kaynak ve kabiliyetlerin üzerine rekabet stratejilerinin ve pazar pozisyonunun inşa edilmesi gerektiğini ileri sürmüştür (Barca, 2009: 46). Grant (1991: 116) rekabetçi avantaj sunan KTG çerçevesinde strateji oluşturmayı irdelediği çalışmasında firma kaynak ve kabiliyetlerinin uzun vadeli strateji için temel oluşturması gerektiğini iki sayıltıya bağlamıştır. Bunlardan ilkini iç kaynakların ve kabiliyetlerin firmanın stratejisi için yön gösterici olması, ikincisini de kaynak ve kabiliyetlerin firmanın karı için en önde gelen unsur olması şeklinde belirtmiştir. KTG'nin kökenlerinde bulunan Ricardocu gelenekten (Barney ve Clark, 2007: 5) hareketle Grimm ve arkadaşları (2006: 134) örgütsel kaynakların, Porter'ın rekabet stratejileri üzerindeki etkisine olan önemine dikkat çekmiştir. Yazarlara göre firmanın büyük ölçekli bir tesise ya da madde/malzeme maliyet avantajına sahip olması düşük maliyet eylemleriyle ve yüksek kaliteli ürünlere sahip olması da seçkin fiyat eylemleriyle Ricardiyan rantı elde etmesine olanak sağlamaktadır. Benzer şekilde Conner (1991: 132) çalışmasında KTG'de ayırdedicilik kavramını incelemiş gerek ürün sunumundaki farklıık gerekse düşük maliyet açısından ayırt edici olabilmek için ayırt edici özellikteki kaynaklara vurgu yapmıştır. Tüm bu ifadelerden anlaşııı̆ı̆ üzere KTG, strateji-kaynak ilişkisinde geleneksel bakış açısının aksine strateji seçiminde mevcut kaynakların dikkatli değerlendirilmesinin rol oynadığını vurgulamaktadır (Spanos ve Lioukas, 2001: 22). Bu araştırmada da yukarıda tartışılan hususlar çerçevesinde araştırmanın kuramsal çerçevesi oluşturulmuş, KTG ekseninde örgütsel kaynaklardan maddi kaynakların maliyet liderliği stratejisini, maddi olmayan kaynakların (entelektüel sermaye) ise farklılaşma stratejisini etkileyeceği ileri sürülmüştür. 
Maliyet liderliği stratejisi için gerekli kaynaklar olarak büyük-ölçekli üretim, büyük miktarda satış rakamları (Gao vd., 2010: 382), etkili dağıtım kanalları, sermaye yatırımı ve sermayeye erişim (Porter, 1980: 40) örnek verilmiştir. Firma aktiflerinin hem duran varlıklar hem de dönen varlıklar ile ilgili olduğu ve maddi kaynakları ifade ettiği bilinmektedir (Fahy ve Smithee, 1999: 7; Hollensen ve Opresnik, 2019: 79). Duran varlıklar içerisinde büyük-ölçekli üretim ve etkili dağıtım kanalları için kullanılan tüm makine ve teçhizat yer almaktadır. Büyük miktarda satış rakamlarına konu olan stoklar ve satış getirileri ise dönen varlıklar içerisinde kendine yer bulabilmektedir (Sevilengül, 2008). Ayrıca firma sermayesi esasen firma aktifleri ile doğrudan ilgilidir. Sermaye genel anlamı itibariyle, firmanın mal ve hizmet üretmesi amacıyla elinde bulundurduğu ve bilançonun aktiflerinde yer alan nakit, alacak, stok, haklar ve duran varlıklardan oluşmaktadır (Terim ve Kayalı, 2009: 126). Buradan hareketle gerek finansal gerek fiziksel kaynakların maddi kaynaklar olarak maliyet liderliği stratejisi için önemli bir kaynak olduğu varsayılmaktadır. Padilha ve arkadaşları (2017) kuyumculuk sektöründe faaliyet gösteren 25 firma üzerinde strateji geliştirmede maddi kaynakların ve maddi olmayan kaynakların etkisini araştırmıştır. 25 firmadan sadece birinde (üretim yapan bir firma) maliyet liderliği stratejisinin uygulandığı belirlenen çalışmada maddi kaynaklardan teknoloji, teçhizat, hammadde kaynaklarına erişim ve depolamanın maliyet liderliği stratejisinin uygulamasıda önemli birer unsur olduğu bulgulanmıştır. Ni (2008) kamyon taşımacılığı sektöründe yer alan 332 firmanın üst yöneticisi ile gerçekleştirdiği çalışmada operasyonel ve lojistik kaynakların- ekipman kullanımı ve yatırılan sermayenin verimliliğini artıran - maliyet liderliği stratejisi ile birleştiğinde üstün performansa yol açacağını belirtmiş ancak bunu doğrulayamamıştır. Cater ve Cater (2009) üretim, hizmet ve ticaret sektöründeki 182 firma ile gerçekleştirdiği çalışmasında finansal ve fiziksel kaynakların maliyet liderliği temelli rekabet avantajı ve farklılaşma temelli rekabet avantajı üzerindeki etkisini incelemiştir. Fiziksel kaynaklar duran varlıklar, finansal kaynaklar ise son üç yıldaki geçmiş yıl karları üzerinden değerlendirilmiştir. Bulgular, finansal kaynakların hem maliyet liderliği hem farklılaşma temelli rekabet avantajı üzerinde etkili olduğunu, fiziksel kaynakların ise her iki rekabet avantajı için de etkisinin bulunmadığını göstermiştir. Walsh ve arkadaşları (2008) fiziksel sermayenin maliyet liderliği stratejisi üzerinde etkisinin bulunmadığını bulgulamıştır. Bunun yanı sıra Grant (1991: 118) fiziksel kaynaklar ile rekabet avantajı arasındaki ilişkiyi değerlendirirken firma duran varlıkları içerisinde yer alan tesis büyüklüğünün farklılaşma avantajından ziyade maliyet avantajı için önemli bir kaynak oluşturduğunu belirtmiştir. Yine, Kaleka (2002: 279) fiziksel kaynakların maliyet avantajının elde edilmesinde etkili olduğunu ifade etmiştir.

Porter (1980: 41) farklılaşma stratejisi için gerekli olan örgütsel kaynakların güçlü pazarlama becerileri, ürün mühendisliği, yaratıcı yetenekler, güçlü temel araştırma yetenekleri, kalite veya teknolojik liderlikte kazanılmış kurumsal itibar, sektörde uzun bir geçmiş veya diğer işlerden elde edilmiş benzersiz beceriler kombinasyonu ve kanallarla güçlü iş birliği olduğunu belirtmektedir. França ve Rua (2018: 166) ayakkabı ihracatı gerçekleştiren küçük ve orta büyüklükteki 42 firma ile yürüttüğü çalışmasında farklılaşma stratejisi üzerinde etkili maddi olmayan kaynakları insani ve kültürel kaynaklar, enformasyonel kaynaklar, itibar, ilişkisel kaynaklar, bilgi işleme ve sektörel bilgiyi elde etme olarak belirtmiştir. Küçük ve orta ölçekli hintkamışı üreten 38 firma üzerinde gerçekleştirilen bir diğer çalışma, maddi olmayan kaynakların (insan sermayesi, yapısal sermaye ve sosyal sermaye) Porter'ın rekabet stratejilerinin seçimi üzerinde etkili olduğunu (Husnah vd., 2013: 21) ortaya koymuştur. Belirtilen çalışmada rekabet stratejileri maliyet liderliği, odaklanma ve farklılaşma stratejilerinden oluşan bir bütün olarak değerlendirilmiştir. Gana'da üretim ve hizmet sektöründe faaliyet gösteren 200 orta ve büyük ölçekteki firmanın 
yer aldığı bir çalışmada sosyal sermaye diğer firmaların üst yönetimlerinden, cemiyet liderlerinden ve hükümet yetkililerinden elde edilen sosyal sermaye olarak üç boyut altında incelenmiş ve her bir boyutun farklılaşma stratejisi üzerinde etkili olduğu tespit edilmiştir (Acquaah, 2007). Mizumoto ve Saes (2010) 409 Brezilyalı kahve üreticisi ile bir çalışma yürütmüştür. Illgili çalışmada bazı girişimcilerin zamanla düşük-maliyet ile üretim stratejisinin yerine farklılaşma stratejisine uyum sağladığı ve bu uyumun arkasındaki nedenin de insan sermayesi ile sosyal sermayeye olan yatırım olduğu bulgulanmıştır. Endonezya'nın Gorontalo vilayetinde üretim sektöründe yer alan 68 küçük ve orta ölçekli firma, insan sermayesinin performans üzerindeki etkisinde strateji oluşturmanın aracı rolü açısından incelenmiştir. Çalışma ile insan sermayesinin farklılaşma stratejisi üzerinde orta derece etkiye sahip olduğu tespit edilmiştir (Ariawan, 2018). Adedoyin ve Ezenwakwelu (2019) Nijerya'daki 10 mevduat bankasının 300 banka çalışanı ile gerçekleştirdiği çalışmasında maddi olmayan kaynakların rekabet avantajı üzerindeki etkisini sorgulamıştır. Çalışma bulgularına göre rekabet avantajı boyutlarından biri olan farklılaşma stratejisi boyutunu maddi olmayan pazarlama kaynaklarının, maddi olmayan teknoloji kaynaklarının ve yapısal sermayenin pozitif yönde etkilediği belirlenmiştir. Walsh ve arkadaşları (2008) maliyet liderliği stratejisini ya da farklılaşma stratejisini benimseyen 538 otel ile yürüttükleri çalışmada entelektüel sermayenin performans üzerindeki etkisini araştırmıştır. Çalışma ile sistemsel sermaye (yapısal sermaye), müşteri sermayesi ve insan sermayesinin farklılaşma stratejisini benimseyen firmalar üzerinde pozitif yönde etkiye sahip olduğu sonucu elde edilmiştir. Son olarak Cater ve Cater (2009) insan sermayesinin ve yapısal sermayenin farklılaşma temelli rekabet avantajı üzerinde müşteri sermayesinin ise hem farklılaşma temelli hem de maliyet liderliği temelli rekabet avantajı üzerinde etkili olduğunu ortaya koymuştur.

Araştırmanın amacı doğrultusunda KTG ekseninde örgütsel kaynakların rekabet stratejileri üzerindeki etkisini incelemek amacıyla aşağıdaki sorulara yanıt aranmaktadır:

- Örgütün maddi kaynaklarının maliyet liderliği stratejisi üzerindeki etkisi nasıldır?

- Örgütün maddi olmayan kaynaklarının (insan sermayesi, sosyal sermaye ve yapısal sermaye) farklılaşma stratejisi üzerindeki etkileri nasıldır?

\subsection{Sektörlerin Teknolojik Sınıflamasına ve Firmaların Ortaklık Yapısına Göre Örgütsel Kaynaklar ve Rekabet Stratejileri}

Firmaların faaliyet gösterdiği sektöre göre firmanın maddi kaynaklarının farklılaştığı ifade edilebilir (Talberg, 2008: 181). Öyle ki, Abor (2007) Gana'da 150 küçük ve orta ölçekli firmanın üzerinde endüstri sınıflamasının sermaye yapısı ile olan etkileşimini araştırmış, faaliyet gösterilen sektöre göre firma sermaye yapısının farklılaştığını bulgulamıştır. Maddi kaynaklar ile etkileşimde olan bir diğer değişken de firmanın ortaklık yapısıdır. Firmanın ortaklık yapısına göre sermaye yapısına ilişkin alınan kararlar değişiklik göstermektedir (Wellalage ve Locke, 2014: 127). Diğer taraftan maddi olmayan kaynaklara yani entelektüel sermayeye ilişkin olarak; firmaların faaliyet gösterdikleri sektörün türü ve firma ortaklık yapısı ile firmaların entelektüel sermaye açıklama düzeyleri arasındaki etkileşimin alanyazında çok defa araştırıldığı görülmektedir. Whiting ve Woodcock (2011) Avusturalya Menkul Kıymetler Borsası'nda faaliyet gösteren 2036 firma üzerine gerçekleştirdiği analizlerde teknoloji temelli ve bilgi-yoğun sektörlerde faaliyet gösteren firmaların diğer sektörlerde yer alan firmalara göre açıklanan entelektüel sermaye düzeylerinin (içsel sermaye, dışsal sermaye ve insan sermayesi) daha kapsamlı olduğunu, firmanın sahiplik yapısının ise entelektüel sermaye oluşumunda bir etkisinin bulunmadığını bulgulamıştır. Diğer bir çalışma da Muttakin ve arkadaşları (2015) tarafından Dhaka Menkul Kıymetler Borsası'nda işlem gören 116 firma ile gerçekleştirilmiştir. Çalışmada yabancı sermayeli 
ortak yapısının entelektüel sermaye açıklama düzeyi üzerinde pozitif yönde etkili olduğu görülmüştür. Bozzolan ve arkadaşları (2006) ise 30 İtalyan ve 30 İngiliz firma ile yürüttükleri çalışmasında endüstri türünün (geleneksel-bilgi yoğun endüstri) entelektüel sermaye açıklama düzeyi (içsel sermaye, dışsal sermaye ve insan sermayesi) üzerinde etkili olduğunu tespit etmiştir. Her ne kadar entelektüel sermaye açıklama düzeyi firmaların entelektüel sermaye düzeylerini tanımlamasa da entelektüel sermaye açıklama düzeyinin sektör ve ortaklık yapısı ile olan etkileşiminden hareketle firmaların maddi olmayan kaynaklarının (entelektüel sermaye) firmaların faaliyet gösterdiği sektörün teknolojik sınıflamasına ve firmaların ortaklık yapısına göre farklılaşacağı varsayılabilir.

Firmaların faaliyet gösterdikleri sektörün sınıflandırması ve firma ortaklık yapısı firmaların strateji seçimi üzerinde önemli rol oynamaktadır. Zhang ve arkadaşları (2019) Çin'de araba sektöründe faaliyeti bulunan 30 firma üzerinde ortaklık yapısının firma stratejisi seçimindeki etkisini incelemiştir. Çalışma bulgularına göre ortak girişim olan yabancı sermayeli firmaların daha çok farklılaşma stratejisine yöneldiği belirlenmiştir. Ayrıca çevrenin daha dinamik olduğu yüksek-teknoloji sektörlerde firmaların farklılaşma stratejisini uyguladığı, teknolojinin daha düşük olduğu istikrarlı çevrelerde ise firmaların maliyet liderliği stratejisini uygulamayı seçtiği bilinmektedir (Ergün, 2018: 30).

Firmaların ortaklık yapısı ve sektör sınıflamasının entelektüel sermaye ve rekabet stratejileri üzerinde belirleyici olduğu ifade edilebilir. Bu araştırmada ortaklık yapısı ve sektör sınıflaması değişkenlerine göre entelektüel sermaye ve rekabet stratejilerinin nasıl farklılaştığını ortaya koymak araştırmanın diğer bir amacıdır. Dolayısıyla aşağıdaki soruya yanıt aranmaktadır:

- Firmaların maddi kaynaklar (aktifler), maddi olmayan kaynaklar (insan sermayesi, sosyal sermaye ve yapısal sermaye) ve rekabet stratejileri (maliyet liderliği stratejisi ve farkIılaşma stratejisi), firmaların faaliyet gösterdikleri sektörlerin teknolojik sınıflamasına (düşük teknoloji, orta-düşük teknoloji, orta-yüksek teknoloji ve yüksek teknoloji) ve firmaların ortaklık yapısına (tamamen yabancı sermaye, tamamen yerli sermaye ve hem yerli hem yabancı sermaye) göre farklılık gösterir mi?

\section{Araştırmanın Yöntemi}

\subsection{Araştırmanın Modeli}

Araştırma nicel araştırma deseni içerisinde yer alan ilişkisel tarama modeli kullanılarak yürütülmüştür. İlişkisel tarama modeli, iki ya da daha fazla değişken arasındaki ilişkiyi belirlemek ve neden-sonuç ile ilgili ipuçları elde etmek için kullanılmaktadır (Büyüköztürk vd., 2008).

\subsection{Prosedür}

Araştırma evrenini İstanbul Sanayi Odası'nın yayınladığı birinci ve ikinci 500 listelerinde yer alan Türkiye'nin ilk 1000 üretici sanayi firması oluşturmaktadır. Firmalardan 15 tanesi kamuya bağlı kuruluş olması nedeniyle evren içerisinden ayıklanmıştır. Ayrıca firmalardan 50 tanesi listelerde isimlerinin yer almasını istememiştir. Bu doğrultuda 935 firmaya tam sayım yöntemi ile katılımcı bilgi formu ve ölçekler uygulanmıştır. Stratejik yönetim sürecinin temelinde öncelikle stratejik bilinç sahibi olmak yer almaktadır. Bu doğrultuda ölçekler firmaların stratejileri hakkında bilgi sahibi orta ve üst düzey yöneticilerine uygulanmış ve 213 firmadan veriler elde edilmiştir. 


\subsection{Katılımcı Profili}

Araştırmaya katılan firmaların 105 tanesi iso birinci 500, 106 tanesi iso ikinci 500 listesinde yer almaktadır. Ayrıca 2 katılımcı listelerdeki yerinin belirtilmesini istememiştir. Katılımcı firmalardan 164 tanesi tamamen yerli sermaye, 31 tanesi hem yerli hem yabancı sermaye, 16 tanesi tamamen yabancı sermaye ile faaliyet göstermektedir ( 2 tanesine ait ortaklık yapısı paylaşılmamıştır). Firmaların faaliyet gösterdiği sektörler düşük yoğunluklu sektörler, orta-düşük teknoloji yoğunluklu sektörler, orta-yüksek teknoloji yoğunluklu sektörler ve yüksek teknoloji yoğunluklu sektörler olarak sınıflandırılmıştır (Eurostat, 2019; TOBB, 2019). Bu doğrultuda firmaların 76 tanesi düşük teknoloji sektörlerde, 72 tanesi orta-düşük teknoloji sektörlerde, 60 tanesi orta-yüksek teknoloji sektörlerde ve 3 tanesi ise yüksek teknoloji sektörlerde faaliyet göstermektedir.

\subsection{Araştırmada Kullanılan Ölçekler}

Araştırmada kullanılan entelektüel sermaye ölçeği (ES-Ö) ve rekabet stratejileri ölçeği (RSÖ) alanyazında daha önceden kullanılmış, güvenirlilik ve geçerliği kanıtlanmış ölçeklerdir. Bu ölçeklerin alt boyutlarıyla da ayrı ayrı birer ölçek olarak kullanıldığı görülmektedir. Ancak araştırma kapsamında ölçekler bir bütün olarak uygulanmıştır. Araştırmada bir de katılımcı bilgi formu yer almaktadır.

Örgütsel kaynaklar ölçümünde maddi kaynaklar ve maddi olmayan kaynakların ayrımı yapılmıştır. Maddi kaynakların ölçümünde ilgili firmaların aktiflerine karşılık gelen değer maddi kaynaklarının temel göstergesi olarak ele alınmıştır. Maddi olmayan kaynakların ölçümünde insan sermayesini ölçmek üzere 5 ifadeden oluşan (Schultz, 1961; Snell \& Dean, 1992) insan sermayesi ölçeği; sosyal sermayeyi ölçmek üzere 5 ifadeden oluşan sosyal sermaye ölçeği (Burt, 1992; Gupta \& Govindarajan, 2000) ve yapısal sermayeyi ölçmek için 4 ifadeden oluşan örgütsel sermaye ölçeğinden (Davenport \& Prusak, 1998) yararlanılmıştır. Ayrıca Subramaniam ve Youndt (2005) tarafından bu üç ölçekte yer alan 14 ifade Entelektüel Sermaye Ölçeği olarak 7'li Likert tipinde (1-kesinlikle katılmıyorum, 7-kesinlikle katılıyorum) kullanılmıştır. Ölçekte yer alan bazı ifadeler "çalışanlarımız genellikle sektörün en iyileri olarak kabul edilir", "çalışanlarımız bilgiyi paylaşır ve birbirinden öğrenir", "şirketimiz bilgiyi elde etmek için patent/lisans kullanır" şeklindedir. Yapılan doğrulayıcı faktör analizi sonucunda ölçüm modelinin uyum indekslerinin kabul edilebilir düzeyde olduğu belirtilmiştir (Ki-kare/Sd: 133.54/48 = 2.78; CFI: ,91; GFI: ,87; IFI: ,92).

Zahra ve Covin (1993) firma düzeyinde rekabet stratejilerini ölçmek üzere geliştirdiği ölçek Luo ve Zhao (2004) tarafından revize edilmiştir. Luo ve Zhao'nun (2004) çalışmasında maliyet liderliği stratejisi ölçeği ve farklılaşma stratejisi ölçeği bulunmaktadır. Ölçeklerin güvenirlik analizi bulgularında Cronbach Alfa katsayısı sırasıyla .75 ve .72'dir. Ölçekler Luo ve Zhao'nun (2004) revize ettiği haliyle Parnell (2011) tarafından kullanılmıştır. Parnell (2011) çalışmasında maliyet liderliği stratejisi ölçeği ve farklılaşma stratejisi ölçeğine ilişkin üç farklı örneklemdeki güvenirlik analizi bulgusunu .60'ın (Cronbach Alfa Katsayısı) üzerinde tespit etmiştir. Ölçeklerin revize edilmiş halinde maliyet liderliği stratejisi ölçeği için 5 ifade ve farklılaşma stratejisi ölçeği için 7 ifade yer almaktadır. Bu araştırmada her iki ölçeğe ait toplam 12 ifade ve 5'li Likert tipi (1-hiç önemli değil, 5-çok önemli) biçiminde oluşturulan Rekabet Stratejileri Ölçeği kullanılmıştır. Ölçekte yer alan bazı ifadeler "hammadde ya da malzeme teminindeki verimlilik", "maliyetleri azaltmanın yollarını bulma", "pazara sunulan yeni ürün miktarı", "güçlü marka kimliği oluşturma" şeklindedir. 
Araştırmada ölçeklerin Türkçeye çevrisinde ileri çeviri tekniği kullanılmıştır. İleri çeviri tekniği ile bir ya da daha fazla çevirici kaynak dildeki ölçeği hedef dile çevirir. Daha sonra kaynak dildeki ve hedef dildeki ölçeklerin denkliği başka bir grup çevirici tarafından kontrol edilir. (Hambleton, 1996:14; Hambleton, 2005: 12). Ileri çeviri tasarımları, ölçeğin hem kaynak hem de hedef dil versiyonlarını incelendiğinden iki dildeki eşdeğerlik hakkında güçlü kanıtlar sunar (Hambleton ve Patsula, 1999: 161). Araştırmada kullanılan ölçekler İngilizce 'den Türkçe 'ye alanında uzman 3 akademisyen tarafından çevrilmiştir. Daha sonra her iki dildeki ölçeklerin denkliği alanında uzman 2 akademisyen ve iso listelerinde yer alan 1 firma yöneticisi tarafından kontrol edilmiştir.

\subsection{Verilerin Analizinde Kullanılan Yöntemler}

Araştırmada verilerin analizinde SPSS 22.0 programı kullanılmıştır. Araştırmada kullanılan ölçeklerin geçerliğinin belirlenmesi için faktör analizi gerçekleştirilmiştir. Ölçeklerin güvenirliğinde ise Cronbach Alfa katsayısından yararlanılmıştır. Araştırma verilerinin çözümlenmesi, pearson moment korelasyon katsayı değerleri, regresyon analizi, ikiden fazla bağımsız grup için tek yönlü varyans analizi, varyans analizinde gruplar arasındaki farklılığın hangi grup ya da gruplardan kaynaklandığının belirlenmesi için Tukey testi kullanılarak gerçekleştirilmiştir.

\subsection{Geçerlik ve Güvenirlik Bulguları}

Keşfedici faktör analizi, bir kuram çerçevesinde geliştirilen ölçme araçlarının kuramsal yapıyı temsil eden daha alt düzeydeki boyutlarını tanımlamayı amaçlamaktadır (Çokluk vd., 2010: 186). Geçerli bir ölçüm aracının geçerli olmasının yanında güvenilir de olması gerekmektedir. Güvenirlik bir ölçeğin ölçmek istediği kavramı tutarlı ve istikrarlı bir şekilde ölçmesini ve hatalardan uzaklaşma derecesini ifade etmektedir (Peter, 1979: 6). Tablo 1 keşfedici faktör analizi ve güvenirlik analizi bulgularını içermektedir.

Tablo 1: Ölçeklere ilişkin Keşfedici Faktör Analizi Bulguları

\begin{tabular}{|c|c|c|c|c|c|}
\hline Ölçek & Faktörler & $\begin{array}{l}\text { Madde } \\
\text { Sayısı }\end{array}$ & $\begin{array}{l}\text { Fak. Yük. Ara- } \\
\text { lığı }\end{array}$ & $\begin{array}{c}\text { Açıklanan Var- } \\
\text { yans (\%) }\end{array}$ & $\begin{array}{l}\text { Cronbach } \\
\text { Alpha }(\alpha)\end{array}$ \\
\hline \multirow{5}{*}{ 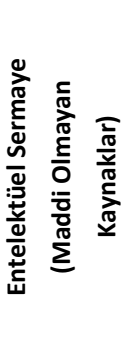 } & ES-Ö (MOK) & 14 & & 58,725 & ,860 \\
\hline & - Insan Sermayesi & 5 & $\begin{array}{c}, 52 ;, 71 ;, 72 ; \\
72.77\end{array}$ & 19,384 & 824 \\
\hline & - Sosyal Sermaye & 5 & $\begin{array}{c}, 51 ;, 52 ;, 78 ; \\
, 79 ;, 85\end{array}$ & 22,761 & ,794 \\
\hline & - Yapısal Sermaye & 4 & $\begin{array}{c}, 53 ;, 63 ;, 77 ; \\
, 81\end{array}$ & 16,580 & ,675 \\
\hline & \multicolumn{5}{|c|}{ KMO:,850; Barlett: 1166,008; $d f=91 ; p<0,001$} \\
\hline \multirow{4}{*}{ 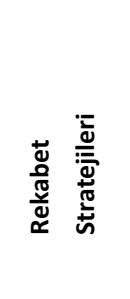 } & RS-Ö & 12 & & 50,121 & ,816 \\
\hline & - Maliyet Liderliği & 5 & $\begin{array}{c}, 56 ;, 57 ;, 66 ; \\
, 69 ;, 74\end{array}$ & 19,424 & 664 \\
\hline & - Farklılaşma & 7 & $\begin{array}{c}, 48 ;, 60,60 ; \\
, 65 ;, 81 ;, 87 ; \\
, 88\end{array}$ & 30,697 & ,843 \\
\hline & \multicolumn{4}{|c|}{ KMO değeri: ,797 Barlett: 936,552; $d f=66 ; p<0,001$} & \\
\hline
\end{tabular}


Tablo 1'de maddi olmayan kaynaklar (entelektüel sermaye) ölçeği için KMO örneklem yeterliliği katsayısı 0,850; ki-kare değeri 1166,008 ve Barlett Küresellik Testi $(p<0,001)$ manidardır. Elde edilen değerler örneklem büyüklüğünün ve verilerin faktör analizi için uygun olduğunun bir göstergesidir. Faktör analizi sonucunda ifadeler alanyazınla uyumlu bir şekilde üç faktör altında toplanmıştır. Toplam ifade sayısı 14 'tür. Üç faktörlü yapı toplam varyansın \%58,725'ini açıklamaktadır. Ayrıca ES-Ö’nün güvenirlik analizi bulgusu Cronbach Alfa Katsayısı ,860 ve yüksek güvenilirlik seviyesindedir. İnsan sermayesi boyutuna ilişkin değer ,824; sosyal sermaye için ,794 ve yapısal sermaye için ,675'dir. Her bir faktör boyutu için güvenirlik yeterli düzeydedir.

RS-Ö’nün KMO örneklem yeterliliği katsayısı ,797'dir. Barlett Küresellik Testi $(p<0,001)$ manidardır. Bu verilere istinaden örneklem büyüklüğünün faktör analizi için yeterli ve ölçme aracının faktör çıkarmaya uygun olduğu ifade edilebilir. Tablo 1 incelendiğinde RS-Ö’nün iki faktöre ayrıldığı görülmektedir. Toplam ifade sayısı 12 'dir. İfadeler alanyazınla uyumlu şekilde ilgili faktörlerin altında toplanmıştır. RS-Ö'ye ilişkin açıklanan toplam varyans \%50,121'dir. Öte yandan rekabet stratejileri ölçeğinin güvenirlilik analizi bulgusu Cronbach Alfa Katsayısı: ,816 ve yüksek güvenilirlik seviyesindedir. Ayrıca maliyet liderliği stratejisine ilişkin değer ,664 ve farklılaşma stratejisi boyutu için ,843’dür. Her bir faktör boyutunun güvenirliği yeterli düzeydedir.

\subsection{Araştırmanın Bulguları}

Araştırmada öncelikle maddi kaynaklar, insan sermayesi, sosyal sermaye, yapısal sermaye, maliyet liderliği stratejisi ve farklılaşma stratejisi değişkenlerine ait ortalama, standart sapma ve Pearson moment korelasyon katsayıları sunulmuştur. Bu doğrultuda Tablo 2' de betimsel istatistikler ve değişkenler arasındaki korelasyon sonuçları yer almaktadır.

Tablo 2: Değişkenlere Ait Ortalama, Standart Sapma ve Korelasyon Katsayıları

\begin{tabular}{|c|c|c|c|c|c|c|c|c|}
\hline Değişkenler & Ort. & Ss & (1) & (2) & (3) & (4) & (5) & (6) \\
\hline 1. Maddi kaynaklar & $678,3^{1}$ & 1736,2 & 1 & & & & & \\
\hline 2. İnsan sermayesi & 5,70 & 670 & ,041 & 1 & & & & \\
\hline 3. Sosyal Sermaye & 5,72 & 698 &,- 035 &, $583^{* * *}$ & 1 & & & \\
\hline 4. Yapısal Sermaye & 6,12 & 751 &,- 027 &, $460^{* * *}$ &, $375^{* * *}$ & 1 & & \\
\hline 5. Maliyet Liderliği Stratejisi & 4,62 & ,365 & ,130 & , 050 & 028 & ,033 & 1 & \\
\hline 6. Farklılaşma Stratejisi & 4,10 & ,626 & ,036 &, $310^{* * *}$ &, $235^{* * *}$ & $420^{* * *}$ &, $301^{* * *}$ & 1 \\
\hline
\end{tabular}

${ }^{* *} \mathrm{p}<0,05 ;{ }^{* * *} \mathrm{p}<0,001 ;{ }^{1}$ Milyon TL

Maddi kaynaklar değişkenine ilişkin olarak firmaların aktif değerlerinin ortalaması 678,3 milyon TL olarak hesaplanmıştır. Maddi olmayan kaynaklar incelendiğinde entelektüel sermaye boyutlarından yapısal sermaye boyutu ortalamasının $(\bar{X}=6,12)$ insan sermayesi ve sosyal sermaye boyutlarına göre daha yüksek düzeyde olduğu görülmektedir. Bununla beraber rekabet stratejileri alt boyutlarından maliyet liderliği strateji boyutunun ortalamasının $(\bar{X}=4,62)$ da yüksek olduğu anlaşılmaktadır. Diğer yandan, Pearson Moment Korelasyon katsayı değerleri incelendiğinde maddi kaynakların hem maddi olmayan kaynaklar hem de rekabet stratejileri ile ilişkili olmadı̆̆ı $(p>0,05)$ ifade edilebilir. Maddi olmayan kaynaklar değerlendirildiğinde ise insan sermayesi, sosyal sermaye ve yapısal sermayenin maliyet liderliği stratejisi ile ilişkilerinin bulun- 
madığı $(p>0,05)$ ancak farklılaşma stratejisi ile pozitif ilişki $(p<0,001)$ gösterdikleri görülmektedir. Son olarak maliyet liderliği stratejisi ile farklılaşma stratejisi arasındaki ilişkini pozitif ve anlamlı $(p<0,001)$ olduğu belirtilebilir.

Araştırmada bundan sonraki aşamada regresyon analizleri gerçekleştirilmiştir. Bu doğrultuda maddi kaynakların maliyet liderliği stratejisi üzerindeki açıklayıcılığını belirlemek amacıyla yapılan regresyon analizi bulguları Tablo 3'teki gibidir.

Tablo 3: Maddi Kaynakların Maliyet Liderliği Stratejisi Üzerindeki Etkisi

\begin{tabular}{|c|c|c|c|}
\hline $\begin{array}{c}\text { Bağımsız } \\
\text { Değişken(ler) }\end{array}$ & Beta & $t$ değeri & $\mathbf{P}$ \\
\hline Maddi Kaynaklar & ,130 & 992 & ,063 \\
\hline $\begin{array}{l}\text { Bağımlı Değişken: } \\
\text { Maliyet Liderliği Stratejisi }\end{array}$ & Dz. $R^{2:}, 012$ & & $F: 3,491$ \\
\hline
\end{tabular}

Tablo 3 incelendiğinde maddi kaynakların maliyet liderliği stratejisi üzerindeki etkisinin anlamlı olmadığı görülmektedir. Analiz sonucu belirlilik katsayısının $\left(D z . R^{2}\right), 012$ olduğu tespit edilmiştir.

Tablo 4: Maddi Olmayan Kaynakların Farklılaşma Stratejisi Üzerindeki Etkisi

\begin{tabular}{|c|c|c|c|c|}
\hline Bağımsız Değişken(ler) & Beta & t değeri & $\mathbf{P}$ & VIF \\
\hline Constant & - & 3,665 &, $000 * * *$ & \\
\hline İnsan Sermayesi & 135 & 1,668 & 097 & 1,690 \\
\hline Sosyal Sermaye & 025 & ,329 & ,742 & 1,550 \\
\hline Yapısal Sermaye & 349 & 4,934 &, $000 * * *$ & 1,297 \\
\hline $\begin{array}{l}\text { Bağımlı Değişken: } \\
\text { Farklılaşma Stratejisi }\end{array}$ & Dz. $R^{2:}, 183$ & & $\begin{array}{r}\mathrm{F}: 16,8 \\
\text { Durbin Wats }\end{array}$ & \\
\hline
\end{tabular}

${ }^{* *} \mathrm{p}<0,05 ;{ }^{* * *} \mathrm{p}<0,001$

Tablo 4, maddi olmayan kaynakların farklılaşma stratejisi üzerindeki etkisinin $p<0,001$ düzeyinde anlamlı olduğunu ortaya koymaktadır. Oluşturulan modelde bağımsız değişkenler olan insan sermayesi, sosyal sermaye ve yapısal sermaye çoklu doğrusal regresyon analizine maddi olmayan kaynakları temsilen tabii tutulmuştur. Analiz sonuçları yapısal sermayenin farklılaşma stratejisini pozitif yönde etkilediğini $(, 349)$ ve modelin belirlilik katsayısının $\left(D z . R^{2}\right), 183$ olduğunu ortaya koymaktadır. Durbin-Watson testi sonucu otokorelasyon olmadığını göstermektedir. Ayrıca bağımsız değişkenler arasında çoklu doğrusal bağlantı olmadığı tespit edilmiştir.

Araştırmaya katılan firmaların katılımcı profilleri firmaların ortaklık yapısı ve faaliyet gösterilen sektörün teknolojik sınıflaması açısından incelenmiştir. Bu doğrultuda firmaların maddi kaynaklarının, entelektüel sermaye alt boyutlarının ve rekabet stratejileri alt boyutlarının firmaların ortaklık yapısı ve faaliyet gösterilen sektörün teknolojik sınıflaması açısından farklılık gös- 
terip göstermediğini test etmek amacıyla One Way Anova (tek yönlü varyans analizi) analizi yapılmıştır. Analiz kapsamında varyansların eşit olup olmadığının analizi için Levene testinin anlamlılık değerleri incelenmiştir (Kavak vd., 2016). Levene testinin anlamlılık katsayısı ortaklık yapısı üzerinden gerçekleştirilen analizlerde maddi kaynaklar için $p=0,432$; insan sermayesi için $p=0,982$; sosyal sermaye için $p=0,519$; yapısal sermaye için $p=0,491$; maliyet liderliği stratejisi için $p=0,676$ ve farklılaşma stratejisi için $p=0,573$ olarak hesaplanmıştır. Faaliyet gösterilen sektörün teknolojik sınıflaması dikkate alındığında Levene testinin anlamlılık katsayıları maddi kaynaklar için $p=0,198$; insan sermayesi için $p=0,491$; sosyal sermaye için $p=0,925$; yapısal sermaye için $p=0,654$; maliyet liderliği stratejisi için $p=0,875$ ve farklılaşma stratejisi için $p=0,717$ şeklinde belirlenmiştir. Bu değerler $p>0,05$ olduğu için varyansların eşit dağıldığı sonucuna ulaşılmıştır.

Tablo 5'de yer alan ANOVA sonuçları incelendiğinde sosyal sermayenin ortaklık yapısı açısından $(p=0,025 ; p<, 05)$ ve faaliyet gösterilen sektörün teknolojik sınıflamasına $(p=0,013 ; p<, 05)$ göre anlamlı bir şekilde farklılaştığı görülmektedir. Bununla beraber farklılaşma stratejisi de faaliyet gösterilen sektörün teknolojik sınıflamasına $(p=0,003 ; p<, 05)$ göre anlamlı bir şekilde farklılaşmaktadır. Hangi gruplar arasında farklılık olduğunun tespiti amacıyla grupların varyanslarının eşit olması dikkate alınarak Tukey analizi gerçekleştirilmiştir. ANOVA ve Tukey analizi bulguları Tablo 5'de yer almaktadır.

Tablo 5: Ortaklık Yapısı ve Sektörlerine Göre Firmaların Sosyal Sermaye ve Farklılaşma Stratejisine Ilişskin ANOVA ve Tukey Analizi Bulguları

\begin{tabular}{|c|c|c|c|c|c|}
\hline \multicolumn{6}{|c|}{ Ortaklık Yapısı - Sosyal Sermaye (Varyans homojenliği testi: ,519) } \\
\hline $\begin{array}{l}\text { Varyansın } \\
\text { Kaynağı }\end{array}$ & $K T$ & $\boldsymbol{F}$ & Anova $(p)$ & $\begin{array}{c}\text { Gruplar Arası } \\
\text { Farklar (Tukey) }\end{array}$ & $\begin{array}{c}\text { Ortalama } \\
\text { Farkları }\end{array}$ \\
\hline Gruplar arası & 3,530 & & &, $024^{* *}$ & \\
\hline Gruplar içi & 97,665 & 3,759 & $0,025 * *$ & Tamamen Yerli $(\bar{x}: 5,65)$ - Hem Yerli &,- 353 \\
\hline Toplam & 101,195 & & & Hem Yabancı $(\bar{x}: 6,00)$ & \\
\hline
\end{tabular}

Sektör - Sosyal Sermaye (Varyans homojenliği testi: ,925)

\begin{tabular}{|c|c|c|c|c|c|}
\hline $\begin{array}{l}\text { Varyansın } \\
\text { Kaynağı }\end{array}$ & $\kappa T$ & $\boldsymbol{F}$ & Anova $(p)$ & $\begin{array}{c}\text { Gruplar Arası } \\
\text { Farklar (Tukey) }\end{array}$ & $\begin{array}{c}\text { Ortalama } \\
\text { Farkları }\end{array}$ \\
\hline Gruplar arası & 5,086 & & &, $009 * *$ & \\
\hline Gruplar içi & 96,109 & 3,651 &, $013 * *$ & Orta Düşük Teknoloji $(\bar{x}: 5,51)$ - Orta &,- 378 \\
\hline Toplam & 101,195 & & & Yüksek Teknoloji $(\bar{x}: 5,89)$ & \\
\hline
\end{tabular}

Sektör - Farkılaşma Stratejisi (Varyans homojenliği testi: ,717)

\begin{tabular}{|c|c|c|c|c|c|}
\hline $\begin{array}{l}\text { Varyansın } \\
\text { Kaynağı }\end{array}$ & $\kappa T$ & $\boldsymbol{F}$ & Anova (p) & $\begin{array}{c}\text { Gruplar Arası } \\
\text { Farklar (Tukey) }\end{array}$ & $\begin{array}{c}\text { Ortalama } \\
\text { Farkları }\end{array}$ \\
\hline Gruplar arası & 5,289 & & &, $003 * *$ & \\
\hline Gruplar içi & 77,133 & 4,732 &, $003 * *$ & Düşük Teknoloji (x):4,27) - Orta & ,349 \\
\hline Toplam & 82,423 & & & Düşük Teknoloji $(\bar{x}: 3,92)$ & \\
\hline
\end{tabular}

Tukey analizi bulgularına göre hem yerli hem yabancı sermayeli firmaların tamamen yerli firmalara göre sosyal sermayeleri açısından farklılaştığı ve hem yerli hem yabancı sermayeli firmalarda sosyal sermayenin daha yüksek ortalamaya sahip olduğu görülmektedir (tamamen yerli sermayedeki sosyal sermaye $\bar{x}: 5,65$; hem yerli hem yabancı sermayedeki sosyal sermaye $\bar{x}: 6,00)$. Bunun yanı sıra teknolojik yoğunluğun orta-yüksek olduğu sektörlerde faaliyet gösteren firmaların sosyal sermayeleri orta-düşük teknoloji sektörlerde faaliyet gösteren firmalardan farklılaşmaktadır (orta-düşük teknoloji sektördeki sosyal sermaye $\bar{x}$ : 5,51; orta-yüksek teknoloji 
sektördeki sosyal sermaye $\bar{x}: 5,89)$. Son olarak orta-düşük teknoloji yoğunluğundaki sektörlerde faaliyet gösteren firmaların farklılaşma stratejisi açısından düşük teknoloji yoğunluklu sektörlerdeki firmalara göre farklılaştığı görülmektedir (düşük teknoloji sektör farklılaşma stratejisi $\bar{x}$ : 4,27; orta-düşük sektördeki farklılaşma stratejisi $\bar{x}: 3,92$ ).

\section{Sonuç}

Bazı firmaların neden diğerlerine göre daha başarılı olduğunu açıklamak ve bu bağlamdaki performans farklııklarını, rekabet üstünlüğünü yorumlamak stratejik yönetim alanının en temel amacıdır. KTG, örgütün sahip olduğu değerli, nadir, ikame edilemez ve taklit edilemez kaynaklarının sürdürülebilir rekabet üstünlüğü için önemine dikkat çekmektedir. KTG alanyazını incelendiğinde örgütsel kaynakların farklı adlar taşıyan kavramlarla eşanlamlı olarak ele alındığı görülmektedir. Bu araştırmada örgütsel kaynaklar maddi kaynaklar ve maddi olmayan kaynakları temsilen entelektüel sermaye olarak sınıflandırılmıştır. Böylece alanyazındaki örgütsel kaynaklara ilişkin karmaşanın önüne geçilerek alanyazına katkı sağlamak hedeflenmiştir.

KTG'nin kaynakların firmalar arasında heterojen dağılım gösterdiği yaklaşımından hareketle bu dağılımı daha iyi temsil edeceği düşünülerek büyüklükleri ve Türkiye sanayinin ilk 1000 kuruluşu olmaları dolayısıyla ISO birinci 500 ve ISO ikinci 500 firmaları araştırma evreni olarak belirlenmiştir. Bu firmaların orta ve üst düzey yönetimlerinden veriler katılımcı bilgi formu ve ölçekler ile toplanmıştır. Kullanılan ölçeklerin özgün hali dikkate alındığında ölçeklere ilişkin ifadelerin ölçeklerin özgün halleriyle aynı boyutlar altında toplandıkları görülmüştür.

Araştırmada gerçekleştirilen regresyon analizi bulguları örgütün sahip olduğu maddi kaynakların maliyet liderliği stratejisini etkilemediğini ortaya koymaktadır. Maddi kaynaklar örgütün sahip olduğu nakdi değerler ve nakde çevrilebilecek araçları içermektedir. Maddi kaynakları güçlü olan firmalar büyük sermaye yatırımında bulunan etkili dağıtım kanallarına sahip firmalardır. Üretim tesisleri büyük, teknolojileri yeni ve maliyetli, diğer bir ifade ile, makine ve teçhizatı değerli, nakdi imkanları ve sermayeleri güçlü olan firmalar bu gruba dâhil edilmektedir. İlk etapta akıllara bu tarz firmaların izlediği en önemli politikalardan birinin kitle üretimi yapmak ve ölçek ekonomisi ile muazzam satış rakamlarına ulaşmak olduğu böylece marjinal maliyeti olabildiğince düşürmenin hedeflendiği gelebilir. Ancak durum tam olarak böyle gerçekleşmemektedir. Özellikle ülkede hâlihazırda en çok satış yapan firmaların en çok bilinen ve en gelişmiş firmalar olduğu düşünüldüğünde yenilikçiliğe, itibara, markalaşmaya ve pazarlamaya oldukça önem veren firmaların başarılı firmalar arasında yer aldığı görülmektedir. Dolayısıyla bu firmaların güçlü maddi kaynaklara sahip olmaları, onların markalaşma, pazarlama ya da yeni ürünler geliştirme özelliklerinden vazgeçmeleri anlamına gelmemektedir. Buna ek olarak alanyazın incelendiğinde araştırmadan elde edilen bulgular ile benzer bulguların yer aldığı görülmektedir. $\mathrm{Ni}$ (2008) çalışmasında operasyonel ve lojistik kaynaklar ile maliyet liderliği stratejisinin eşleştirilmesi doğrultusunda performans artışının sağlanacağını belirtmiş ancak bu hipotezi doğrulayamamıştır. Walsh ve arkadaşları (2008) fiziksel sermayenin maliyet liderliğini etkilemediğini bulgulamıştır. Cater ve Cater (2009) ise fiziksel sermayenin değil ama finansal sermayenin maliyet liderliği avantajı üzerinde etkili olduğunu ortaya koymuştur. Burada dikkat çeken nokta Ni (2008) ile Walsh ve arkadaşlarının (2008) çalışmalarını hizmet sektöründeki firmalar üzerine gerçekleştirdikleridir. Cater ve Cater (2009) ise çalışmasında hizmet ve ticaret sektöründe bulunan firmalar ile üretim sektöründe faaliyet gösteren firmalara da yer vermiş ve finansal sermayenin maliyet liderliği avantajı üzerinde etkili olduğunu bulgulamıştır. Bu araştırmada ise sadece üretim sektöründe faaliyet gösteren firmalar örneklem olarak seçilmiş ve maddi kaynaklar ak- 
tifler üzerinden tek bir bütün olarak değerlendirilmiştir. Bu doğrultuda hizmet sektöründeki firmaların aksine ayrı ayrı ele alındıkları takdirde fiziksel sermayenin ya da finansal sermayenin üretim firmalarını maliyet liderliği stratejisine yönlendirebileceği ifade edilebilir.

Örgütün maddi olmayan kaynaklarının özellikle yapısal sermayenin farklılaştırma stratejisini etkilediği görülmüştür. Grimm vd. (2006: 33) KTG çerçevesinde patentler, müşteri hizmetleri, ün, marka ve benzerlerinin rekabet avantajının kazanılmasında farklılaşma kaynağı olduğunu ifade etmektedir. Yapısal sermayenin kurumsallaşmış bilgi ve yapı, sistem, süreç, talimat, patentler ile veri tabanlarından oluşan yazılı edinimleri kapsadığı bilinmektedir (Subramaniam ve Youndt, 2005: 451). Dolayısıyla belirtilen bu kaynaklar farklılaşma stratejisi için önemli birer unsur olarak değerlendirilebilir. Yapısal sermaye çalışanın evine giderken götüremediği örgütte kalan bilgidir. Kurumsallaşmış bilgiyi işaret etmektedir. Bu bilgi örgütün yapı, sistem ve süreçlerine işlemiştir. Örgüt bu bilgi aracılığında patentleri ile farklılaşmakta, yeni ürünler geliştirebilmekte, bunun zamanını ve sıklığını ayarlayabilmekte veya farklı olanı markalaşarak ortaya koyabilmektedir. Türkiye bağlamında yenilik firmalar açısından daha çok aşamalı yenilik olarak yorumlanmalıdır. Oldukça radikal olan ve büyük bir değişim içeren radikal yeniliklere nazaran aşamalı yenilikte firmanın kurulu olan bilgi tabanını sıkıca düzenlemek ve sunduğu ürünü veya hizmeti sürekli geliştirmek hedeflenmektedir. İşte böyle bir ortamda firmanın sahip olduğu yapısal sermayenin farklılaşma stratejisi üzerinde etkili olduğu belirtilebilir. Bununla beraber alanyazındaki çalışmalar incelendiğinde özellikle üretim sektöründeki küçük ve orta ölçekli firmaları örneklem olarak seçen çalışmalarda yapısal sermayeden ziyade insan sermayesi ve sosyal sermayenin farklılaşma stratejisi üzerinde etkili olduğu bulgusunun yer aldığını belirtmek mümkündür (Mizumoto ve Saes, 2010; França ve Rua, 2018; Ariawan, 2018). Buradan hareketle yapısal sermayenin içeriğindeki bileşenler ile daha çok büyük ölçekteki firmaların dikkatini çektiği (özellikle firmalar büyüdükçe sistemler üzerinde düşünmeye zaman ayırmakta iletişimi kuvvetlendirmenin yollarını aramaktadır) ve bu alana yoğunlaşılmasıyla da yapısal sermayenin firmayı farklılaşma stratejisine yönlendirdiği düşünülebilir. Diğer yandan hizmet sektöründe faaliyet gösteren oteller (Walsh vd., 2008) ve bankalar (Adedoyin ve Ezenwakwelu, 2019) üzerine yapılan çalışmalarda yapısal sermayenin farklılaşma strateji üzerinde etkisinin olduğu anlaşılmıstır. Bu durum otel ve banka gibi hizmet sektöründe faaliyet gösteren firmaların ortaya çıkarttıkları ürün olan hizmetin farklılaşması için kurumsallaşmış yapı, sistem ve süreçlere ihtiyaç duyduğunu göstermektedir. Benzer şekilde üretim sektöründe faaliyet gösteren büyük firmalar için de kurumsallaşmış yapı, sistem ve süreçlere ihtiyaç vardır. Bunun da firmayı farklılaşma stratejisine yönlendirmesi beklenebilir.

Araştırmaya ilişkin bulgular incelendiğinde hem yerli hem yabancı sermaye sahibi firmaların tamamen yerli sermaye sahibi firmalara oranla daha yüksek sosyal sermaye ortalaması lehine farklılaştığı görülmüştür. Sosyal sermaye örgüt içindeki ve örgüt dışındaki paydaşlarla iletişimin kuvvetli olmasını ifade etmektedir. Hem yerli hem yabancı sermaye sahibi firmalar açısından yabancı kökenli çalışanların olduğu ya da yabancı diğer paydaşlar ile daha sık iletişim kurdukları göz önüne alınırsa bu firmalarda sosyal sermaye ortalamasının daha yüksek sonuç vermesi beklenebilir. Alanyazındaki çalışmalar ise (Whiting ve Woodcok, 2011: 102; Muttakin vd., 2015: 223) yabancı ortaklı firmaların entelektüel sermaye açıklama düzeylerinin yüksek olduğunu göstermiştir. Diğer yandan firmaların faaliyet gösterdikleri sektörler teknolojik olarak sınıflandırıldıklarında orta-yüksek teknoloji sektördeki firmaların orta-düşük teknoloji sektördeki firmalara oranla daha yüksek sosyal sermaye içererek farklılaştığı görülmüştür. Bu durum örgüt içerisin- 
deki uygulamalarda teknoloji kullanımının yüksek olması durumunda örgüt içerisindeki iletişimin de kuvvetleneceği, bilgi paylaşımının hızlanacağı şeklinde yorumlanabilir. Yine, alanyazında yer alan çalışmalar incelendiğinde bilgi yoğun teknoloji sektörlerde faaliyet gösteren firmaların entelektüel sermaye açıklama düzeylerinin daha ileri düzeyde olduğu sonucuna varılmıştır (Whiting ve Woodcock, 2011: 102). Bunun yanı sıra düşük teknoloji sektöründeki firmaların farklılaşma strateji açısından orta-düşük teknoloji sektörlerdeki firmalara göre daha yüksek ortalamaya sahip olduğu ve farklılaştığı belirlenmiştir. Düşük teknoloji sektörler incelendiğinde içerisinde gıda sektörü, içecek sektörü, tekstil sektörü, giyim eşyası sektörü ve mobilya sektörü gibi teknolojinin belki daha az kullanıldığı ama ürün çeşitliliğine ve farklılaşmaya gidilme olasılığı daha yüksek olan sektörlerin yer aldığı görülmektedir. Aksine orta-düşük teknoloji sektörler ise kok kömürü ve rafine edilmiş petrol ürünleri imalatı, fabrikasyon metal ürünleri imalatı, ana metal sanayi, plastik ürünleri sanayi gibi farklılaşma stratejisinin kıyasla daha az uygulanabileceği sektörlerdir.

Sonuç olarak bu araştırma ile iç faktör paradigmasından yararlanılarak rekabet stratejileri üzerindeki etkilerin dış faktörlerden ziyade iç faktörler açısından ne gibi etkileşimler içerdiği anlaşılmaya çalışımıştır. Bu durum, dış faktör paradigması ve örgütün dış çevresinin reddini değil aksine örgütün iç çevresi hesaba katıldığında rekabet stratejileri üzerindeki etkisinin neler olduğunun anlaşıması açısından önemlidir. Bu noktada araştırmada, rekabet stratejilerine iç faktör paradigması ile yaklaşılması, örneklemin üretim sektöründe faaliyet gösteren büyük ölçekli firmalardan oluşması, yalnızca örgütsel kaynakların rekabet stratejileri üzerindeki etkisinin incelenmesi çerçevesinde sınırlııkları bulunmaktadır.

\section{Firmalara Öneriler}

Firmaların piyasa değerinin belirlenmesinde finansman kararları ya da kar dağıtım kararlarının olduğu kadar yatırım kararlarının da oldukça büyük bir etkisi bulunmaktadır. Yatırım kararları verilirken firma maddi kaynaklarının yanı sıra maddi olmayan kaynaklarına da odaklanmaktadır. İşte tüm bu kaynaklar firmanın rekabet avantajı elde etmesi için önemli birer araçtır. Kaynaklar değerli, nadir, ikame edilemez ve taklit edilemez nitelikte olduğu müddetçe yüksek performansın bir kaynağı olacaktır. Maddi kaynaklar açısından değerlendirildiğinde firma mali tablo analizleri ile mali durumunu ve faaliyetlerinin sonuçlarını yorumlamalıdır. Böylece sektör ortalamaları ile karşılaştırmalar yaparak rakiplerine karşı kendi durumunu değerlendirebilecektir. Maddi olmayan kaynaklar bu araştırmadaki karşılığı olan entelektüel sermaye, firmanın soyut olan varlıkları ile katma değer yaratmasına yardımcı olmaktadır. Firmaya özgü örgüt kültürünün oluşturulması, markalaşma, tasarım ve inovasyon gibi faaliyetlerin tümünü firmaların bu kapsamda değerlendirmesi gerekmektedir. Teorik olarak yaklaşıldığında firmanın sahip olduğu bu kaynakları çerçevesinde kendine uyan, rakipleri karşısında kendisini güçlü kılacak bir stratejik pozisyon alması rekabet avantajının sürdürülebilir olmasına olanak sağlayacaktır. Çünkü kaynakların analizi yapılmadan (zayıflıkların ve üstünlüklerin belirlenmediği durum) ve kaynaklara yatırım yapılmadan uygulanmaya çalışılan bir strateji ancak eksik olarak uygulanacaktır.

Kuşkusuz araştırmada ortaya konan en önemli bulgu, yapısal sermayenin farklılaşma stratejisi üzerinde etkisi olduğudur. Firmalar yapısal sermayeye yatırım yaptığı müddetçe farklılaşma stratejisini daha etkin uygulayabilme yeteneğine sahip olacaktır. Örgüt içerisinde örtük olan bilginin ortaya çıkarılması ve örgütte yayılması yapısal sermaye açısından oldukça önemlidir. Örnek vermek gerekirse ülkemiz firmalarında sıklıkla uygulanan insan kaynakları uygulamalarından biri olan iş rotasyonu ile örtük bilginin açığa çıkmasına olanak sağlanmaktadır. Aslında bu durum ülkemizdeki firmalar açısından çoğunlukla mecburiyetten, maliyetleri azaltmak adına bir 
çalışanı birçok yönden değerlendirebilmek amacıyla yapılmaktadır. Ancak bir taraftan da bir yerde saklı olan bilginin yerinde kalmamasına ve açığa çıkmasına yardımcı olmaktadır. Bu noktada, ilişkiler her ne kadar güvene dayalı olsa ve bir yönetici uzun yıllar çalıştı̆̆ı firmada elde ettiği bu deneyim ve tecrübeleri diğer çalışanlar ile paylaşsa da günümüzde çalışanları tatmin etmek, örgüte bağlıık ve sadakatlerini sağlamak oldukça zorlaşmıştır. Böyle bir ortamda artık bunun gibi klasik uygulamaların yerini teknolojiye dayalı veri madenciliği gibi uygulamalar ile bilgiyi depolayarak gerektiğinde o bilgiye ulaşacak ve gelecekle ilgili tahminlerde bulunmaya olanak sağlayacak şekilde tasarlamak daha gerçekçi olacaktır. Böylece çok güvenilen çalışanlar işlerinden ayrılsa bile çalışan sahip olduğu bilgiyi beraberinde götüremeyecek ve örgütte kalan bilgi ile benimsenen strateji daha etkin ya da etkinliğini kaybetmeden uygulanabilecektir.

Araştırmada dikkat çeken bulgulardan bir diğeri yabancı ortağı bulunan firmaların sosyal sermaye açısından farklılaştığının belirlenmesidir. Bu çalışmanın bulgularından biri olmasa da; yeni bağlantılar, yeni fırsatlar ve yeni yatırımlar için yabancı ortaklar ile çalışıımasının firmalara rekabet avantajı kazanma ve daha iyi performans gösterme imkânını yaratacağı ifade edilebilir.

\section{Araştırmacılara Öneriler}

Rekabet stratejilerine ilişkin alanyazın incelendiğinde genel maliyet liderliği ve farklılaşma stratejisine ek olarak farklılaşmaya odaklanma stratejisi, maliyet liderliğine odaklanma stratejisi ve hem maliyet liderliği hem farklılaşma stratejisinin de çalışmalara konu olduğu görülmektedir. Bunun yanı sıra Miles ve Snow'un öne sürdüğü tepkici, analizci, savunmacı ve öncü stratejiler (Miles vd., 1978) de rekabetçi stratejiler olarak çalışılmaktadır. Bu çerçevede bundan sonraki araştırmalarda KTG ekseninde örgütsel kaynakların farklı rekabet stratejileri üzerindeki etkisinin araştırılması önem arz etmektedir. Bununla beraber bu araştırmada örgütsel kaynaklar maddi kaynaklar ve maddi olmayan kaynaklar diğer bir ifade ile entelektüel sermaye olarak sınıflandırılmıştır. Özellikle maddi kaynaklara ilişkin olarak fiziksel ve finansal sermaye ayrımının yapılarak sonraki çalışmalarda incelenmesi alanyazına katkı sağlayacaktır. Diğer yandan KTG ve pozisyon okulu bakış açısının birleştirilerek rekabet stratejileri üzerindeki etkisinin araştırılması da faydalı olacaktır. Ayrıca, rekabet stratejileri ile kaynak ya da kabiliyetlerin eşleştirilmesi çerçevesinde rekabet avantajı ya da firma performasına bağlanması ileriki çalışmalar için araştırılmaya değer olacaktır. Son olarak tüm bu paylaşılanların farklı örneklemlerde araştırılması alanyazına zenginlik getirecektir. 


\section{Eskişehir Osmangazi Üniversitesi IïB Dergisi}

\section{Kaynaklar}

Abor, Joshua (2007), "Industry Classification and the Capital Structure of Ghanaian SMEs", Studies in Economics and Finance, C. 25, S. 3: 207-219.

Acquaah, Moses (2007), "Managerial Social Capital, Strategic Orientation, and Organizational Performance in an Emerging Economy", Strategic Management Journal, C. 28, S. 12: 1235-1255.

Adedoyin, Samuel; Ezenwakwelu, Charity (2019), "The effect of Marketing and Technostructural Intangible Resources in the Nigerian Banking Sector", Management Science Letters, C. 10, S. 2: 287-294.

Akbolat, Mahmut; Işık, Oğuz (2016), "Hastanelerde Rekabet Stratejileri ve Performans”, Atatürk Üniversitesi Sosyal Bilimler Enstitüsü Dergisi, C. 16, S. 1: 401-424.

Alayoğlu, Nihat (2010), "Rekabet Üstünlüğü Sağlamada İnsan Kaynakları ve Rekabet Stratejileri Uyumunun Önemi", İstanbul Ticaret Üniversitesi Sosyal Bilimler Dergisi, C. 9, S. 17: 27-49.

Andrikopoulos, Andreas (2010), "Accounting for Intellectual Capital: on The Elusive Path from Theory to Practice", Knowledge and Process Management, C. 17, S. 4: 180-187.

Ariawan, Ariawan; Sudarma Made; Djumahir, Djumahir; Maski, Ghozali (2018), Is SMEs able to Construct Business Strategy to Improve Its Performance Using Its Own Ability? (Study On SMEs Karawo Handicraft In City of Gorontalo, IndonesIa), Proceedings of the 2nd International Conference of Project Management (ICPM), Gorontalo.

Barca, Mehmet (2009), "Stratejik Yönetim Düşüncesinin Gelişimi”, Asomedya Dergisi, S. 4/5/6: 34-52.

Barca, Mehmet (2017). Economic Foundations of Strategic Management, Routledge: New York.

Baron, Angela; Armstrong, Michael (2007), Human Capital Management: Achieving Added Value Through People, London: Kogan Page.

Barney, Jay Bryan (1986), "Strategic Factor Markets: Expectations, Luck, and Business Strategy", Management Science, C. 32 , S. 10: 1231-1241.

Barney, Jay Bryan (1991), "Firm Resources and Sustained Competitive Advantage”, Journal of Management, C. 17, S. 1: 99-120.

Barney, Jay Bryan; Hesterly, William (1999), “Organizational Economics: Understanding the Relationship Between Organizations and Economic Analysis", Studying Organization: Theory and Method, (Ed. Steward Clegg; Cynthia Hardy), London: Sage Publication: London: 109-141.

Barney, Jay Bryan; Wright, Mike; Ketchen, David Jr. (2001), "The Resource -based View of The Firm: Ten Years After 1991", Journal of Management, C. 27, S. 6: 625-641.

Barney, Jay Bryan; Clark, Delwyn (2007), Resource-Based Theory: Creating and Sustaining Competitive Advantage, New York: Oxford University Press.

Bharadwaj, Sundar (1994), Industry Structure, Competitive Strategy, And Firm-Specific Intangibles as Determinants of Business Unit Performance: Towards an Integrative Model, Doktora Tezi, Texas: Texas A\&M University.

Bridoux, Flore (2004), A Resource-Based Approach to Performance and Competition: An Overview of the Connections Between Resources and Competition, SMS Conference, Porto Rico.

Bontis, Nick; Dragonetti, Nicola; Jacobsen, Kristine; Roos, Göran (1999), "The Knowledge Toolbox: A Review of the Tools Available to Measure and Manage Intangible Resources", European Management Journal, C. 17, S. 4: 391-402.

Bozzolan, Saverio; O’Regan, Philip; Ricceri, Federica (2006), "Intellectual capital disclosure (ICD) A comparison of Italy and the UK", Journal of Human Resource Costing \& Accounting, C. 10, S. 2: 92-113.

Broadbent, Micheal; Cullen John (2003), Managing Financial Resources, Burlington: Butterworth Heinemann.

Brooking, Annie (1996), Intellectual Capital, London: Thomas Business Press.

Burt, Ronald (1992), Structural Holes: The Social Structure of Competition, Cambridge: Harvard University Press.

Büyüköztürk, Şener, Kılıç Çakmak, Ebru, Akgün, Özcan Erkan, Karadeniz, Şirin; Demirel, Funda (2008). Bilimsel Araştırma Yöntemleri, Ankara: Pegem Yayınları.

Cater, Tomaz; Cater, Barbara (2009), “(In)tangible Resources as Antecedents of a Company's Competitive Advantage and Performance", Journal of East European Management Studies, C. 14, S. 2: 186-209.

Chakravarthy, Balaji; Doz, Yves (1992), "Strategy Process Research: Focusing on Corporate Self-Renewal", Strategic Management Journal, C. 13: 5-14. 
Choong, Keong (2008), "Intellectual Capital: Definitions, Categorization and Reporting Models", Journal of Intellectual Capital, C. 9, S. 4: 609-638.

Collis, David; Montgomery, Cynthia (1995), "Competing on Resources: Strategy in the 1990s", Harvard Business Review, C. 73, S. 4: 118-128.

Conner, Kathleen (1991), "A Historical Comprasion of Resource-Based Tehory and Five Schools of Thought Within Industrial Organization Economics: Do We Have a New Theory of Firm?” Journal of Management, C. 17, S. 1: 121154.

Çokluk, Ömay; Şekercioğlu, Güçlü; Büyüköztürk, Şener (2010), Sosyal Bilimler İ̧̧in Çok Değişkenli istatistik, Ankara: Pegem Akademi.

Daou, Alain; Egide, Karuranga; Su, Zhan (2013), "Intellectual Capital in Mexican SMEs From The Perspective of the Resource-Based and Dynamic Capabilities Views", The Journal of Applied Business Research, C. 29, S. 6: 1673-1688.

Davenport, Thomas; Prusak, Laurence (1998), Working Knowledge: How Organizations Manage What They Know, Boston: Harvard Business School Press.

Dierickx, Ingemar; Cool, Karel (1989), "Asset Stock Accumulation and Sustainability of Competıtıve Advantage", Management Science, C. 35, S. 12: 1504-1511.

Ergün, Sinem (2018), "Small/Medium Sized Enterprises and Macro Environment", How Small and Medium-sized Enterprises (SMEs) can be Competitive, (Ed. Sebnem Ensari; Meltem Kiygi-Calli), Lit Verlag: Zürich: 11-43.

Eurostat, (2019), "Glossary: High-tech Classification of Manufacturing Industries", https://ec.europa.eu/eurostat/statistics-explained/index.php/Glossary:High-tech_classification_of_manufacturing_industries,(Erişim: 01.02.2019).

Fahy, John; Smithee, Alan (1999), "Strategic Marketing and the Resource Based View of the Firm", Academy of Marketing Science Review, C. 10, S. 1: 1-21.

Fernandez, Esteban; Montes, Jose; Vazquez, Camilo (2000), "Typology and Strategic Analysis of Intangibles: A ResourceBased Approach", Technovation, C. 20, S.2: 81-92.

Ford, David; Mahieu, Laurent (1998), Operationalising The Resource-Based View of The Firm, International System Dynamics Conference, Quebec.

Foss, Nicolai; Robertson, Paul (2005), "Introduction: Resources, Technology and Strategy", Resources, Technology and Strategy, (Ed. Nicolai Foss; Paul Robertson), Taylor \& Francis: New York: 1-10.

França, Alexandra; Rua, Orlando Lima (2018), "Strategic Determinants of SME Export performance: The Mediating Effect of Competitive Strategy", Entrepreneurship and Structural Change in Dynamic Territories, (Ed. Luisa Cagica CArvalho; Conceiçao Rego; Raquel Lucas; Isabel Sanchez-Hernandez; Backx Noronha), Springer: Cham: 151-174.

Gao, Gerald Yong; Murray, Janet; Kotabe, Masaaki; Lu, Jiangyong (2010), “A “Strategy Tripod” Perspective on Export Behaviors: Evidence from Domestic and Foreign Firms Based in an Emerging Economy", Journal of International Business Studies, S. 41: 377-396.

Görmüş, Alparslan Şahin (2009), "Entelektüel Sermaye ve İnsan Kaynakları Yönetiminin Artan Önemi”, Afyon Kocatepe Üniversitesi iiBF Dergisi, C. 11, S. 1: 57-75.

Grant, Robert (1991), "The Resource-Based Theory of Competitive Advantage: Implications for Strategy Formulation", California Management Review, C. 33, S. 3: 114-135.

Grant, Robert (2013), Contemporary Strategy Analysis Concepts, Techniques, Applications, Cambridge: Blackwell Publishing.

Grimm, Curtis; Lee, Hun; Smith, Ken (2006), Strategy as Action: Competitive Dynamics and Competitive Advantage, New York: Oxford University Press.

Gupta, Anil; Govindarajan, Vijay (2000), “Knowledge Management's Social Dimension: Lessons from Nucor Steel”, Sloan Management Review, C. 42, S. 1: 71-79.

Gümüş, Yusuf (2009), “Lojistik Faaliyetlerin Rekabet Stratejileri ve İşletme Kârı İle Olan İlişkisi”, Muhasebe ve Finansman Dergisi, S. 41: 97-113.

Hambeton, Ronald (1996), "Guidelines for Adapting Educational and Psychological Tests", https://files.eric.ed.gov/fulltext/ED399291.pdf ,(Erişim: 01.02.2019).

Hambleton, Ronald; Patsula, Liane (1999), “Increasing the Validity Of Adapted Tests: Myths to be Avoided and Guidelines for Improving Test Adaptation Practices”, Journal of Applied Testing Technology, C. 1, S. 1, 1-30. 


\section{Eskişehir Osmangazi Üniversitesi IïB Dergisi}

Hambleton, Ronald (2005), "Issues, Designs, and Technical Guidelines for Adapting Tests into Multiple Languages and Cultures", Adapting Educational and Psychological Tests for Cross-Cultural Assessment, (Ed. Ronald Hambleton, Peter Francis Merenda, \& Charles Donald Spielberger), Lawrence Erlbaum: NJ : 3-38.

Harrison, Jeffrey; John, Caron St. (2010), Foundations in Strategic Management, Mason: Cengage Learning.

Hitt, Micheal; Ireland, Duane; Hoskisson, Robert (2009). Strategic Management Concepts and Cases, Mason: Cengage Learning.

Hollensen, Svend; Opresnik, Marc Oliver (2019), Marketing A Relationship Perspective, Singapore: World Scientific Publishing.

Hoopes, David; Madsen, Tammy; Walker, Gordon (2003), “Guest Editors' Introductıon to the Special Issue: Why is There a Resource-based View? Toward a Theory of Competitive Heterogeneity," Strategic Management Journal, C. 24, S. 10: 889-902.

Hsieh, Yi Hua; Chen, Hai Ming (2011), "Strategic Fit Among Business Competitive Strategy, Human Resource Strategy, and Reward System" Academy of Strategic Management Journal, C. 10, S. 2: 11-32.

Husnah; Subroto, Bambang; Aisjah, Siti; Djumahir (2013). "Intangible Assets, Competitive Strategy and Financial Performance: Study on Rattan SMEs in Palu City of Central Sulawesi (Indonesia)", Journal of Business and Management, C. 7, S. 4: 14-27.

Kabue, Lydiah Wanjiru; Kilika, James (2016), "Firm Resources, Core Competencies and Sustainable Competitive Advantage: An Integrative Theoretical Framework", Journal of Management and Strategy, C. 7, S. 1: 98-108.

Kaleka, Anna (2002), "Resources and Capabilities Driving Competitive Advantage in Export Markets: Guidelines for İndustrial Exporters", Industrial Marketing Management, C. 31, S. 3: 273-283.

Kavak, Bahtışen; Taner, Neslişah; Kazancı, Şerife (2016), "Yeniliği Benimseyen Kategorilerinin Yenilikçi Davranış Güdüleri Açısından Farklıııları: Akıllı Telefon Kullanıcıları Üzerinde Bir İnceleme", Pazarlama Teorileri ve Uygulamaları Dergisi, C. 2, S. 2:91-121.

Kittikunchotiwut, Ploychompoo (2015), "The Role of Social Capital on Absorptive Capacity and Organizational Innovation", Journal of Business and Retail Management Research, C. 10, S. 1: 27-39.

Kostopoulos, Konstantinos; Spanos, Yiannis; Prastacos, Gregory (2002), The Resource-Based View of the Firm and Innovation: Identification of Critical Linkages, 2nd European Academy of Management Conference, Stockholm.

Kraaijenbrink, Jeroen; Spender, John; Groen, Aard (2010), "The Resource-Based View: A Review and Assessment of Its Critiques", Journal of Management, C. 36, S. 1: 349-372.

Kristandl, Gerhard; Bontis, Nick (2007), "Defining Intangible Assets and Intellectual Capital”, Management Decision, C. 45, S. 9: $1510-24$.

Lev, Baruch (2001), Intangibles: Management, Measurement and Reporting, Washington: Brookings Institution Press.

Lo, Yin-Hsi (2012), "Managerial Capabilities, Organizational Culture and Organizational Performance: The Resourcebased Perspective in Chinese Lodging Industry", The Journal of International Management Studies, C. 7, S. 1: 151157.

Lopez-Cabarcos, M. Angales; Göttling-Oliveira-Moneiro, Sergio; Vazquez-Rodriguez, Paula (2015), “Organizational Capabilities and Profitability: The Mediating Role of Business Strategy", Sage Open, C. 5, S. 4: 1-13.

Luo, Yadong; Zhao, Hongxin (2004), "Corporate Link and Competitive Strategy in Multinational Enterprises: A Perspective From Subsidiaries Seeking Host Market Penetration”, Journal of International Management, C. 10, S. 1: 77105.

Meyer, Chris; Skaggs, Bruce; Youndt, Mark (2014), "Developing and Deploying Organizational Capital in Services vs. Manufacturing", Journal of Managerial Issues, C. 26, S. 4, 326-344.

Miles, Raymond; Snow, Charles; Meyer, Alan; Coleman Henry (1978), "Organizational Strategy, Structure, and Process", Academy of Management, C. 3, S. 3: 546-562.

Mizumoto, Fabio Matuoka; Saes, Maria Sylvia Macchione (2010), Switching Strategies: Entrepreneur's Human Capital and Social Capital, 19. Encontro da ANPAD, Rio de Janeiro.

Montgomery, Cynthia; Wernerfelt, Birger; Balakrishnan, Srinivasan (1989), "Strategy Content and the Research Process: A Critique and Commentary", Strategic Management Journal, C. 10, S. 2: 189-197.

Moon, Yun Ji; Kym, Hyo Gun (2006), "A Model For The Value of Intellectual Capital”, Canadian Journal of Administrative Sciences, C. 23, S. 3, 253-269. 
Muttakin, Mohammad Badrul; Khan, Arifur; Belal, Ataur Rahman (2015), "Intellectual capital disclosures and corporate governance: An empirical examination", Advances in Accounting, incorporating Advances in International Accounting, C. 31, S. 2: 219-227.

$\mathrm{Ni}, \mathrm{Na}$ (2008), Configurations of Competitive Strategies and Resources: A Set-theoretic Approach, Doktora Tezi, Manitoba: University of Manitoba.

Padilha, Ana Claudia Machado; Gallon, Cristina; Azevedo, Juliana Birkan; Fagundes, Paloma de Mattos; Palma, Aline (2017), "The Dynamics of Strategy and Resources of the Jewelry Sector in Brazil", Espacios, C. 38, S. 12: 7-29.

Parnell, John (2011). "Strategic Capabilities, Competitive Strategy, and Performance Among Retailers in Argentina, Peru and the United States", Management Decision, C. 49, S. 1: 130-155.

Pearce, John; Robinson, Richard (2015), Stratejik Yönetim: Geliştirme, Uygulama ve Kontrol, (Çev. Mehmet Barca), Ankara: Nobel Yayınevi.

Peter, Paul (1979), "Reliability: A Review of Psychometric Basics and Recent Marketing Practices”, Journal of Marketing Research, C. 16, S. 1: 6-17.

Peteraf, Margeret (1993), "The Cornerstones of Competitive Advantage: A Resource-Based View", Strategic Management Journal, C. 14, S. 3: 179-191.

Porter, Michael (1980), Competitive Strategy: Techniques for Analyzing Industries and Competitors, New York: The Free Press.

Porter, Michael (1985), Competitive Advantage: Creating and Sustaining Superior Performance, , New York: The Free Press.

Powell, Thomas (2001), "Competitive Advantage: Logical and Philosophical Considerations", Strategic Management Journal, C. 22, S. 9: 875-888.

Priem, Richard; Butler, John (2001), “Is the Resource-Based 'View' a Useful Perspective for Strategic Management Research?", The Academy of Management Review, C. 26, S. 1: 22-40.

Rumelt, Richard (1984), "Towards a Strategic Theory of the Firm", Competitive Strategic Management, (Ed. Robert Boyden Lamb), Englewood Cliffs: New Jersey: 556-570.

Sanchez, Paloma; Chamichade, Cristina; Olea, Marta (2000), "Management of Intangibles: An Attempt to Build a Theory", Journal of Intellectual Capital, C. 1, S. 4: 188-209.

Schultz, Theodore (1961), "Investment in Human Capital”, The American Economic Review, C. 51, S. 1: 1-17.

Segev, Eli (1989), "A Systematic Comparative Analysis and Synthesis of Two Business-Level Strategic Typologies", Strategic Management Journal, C. 10, S. 5: 487-505.

Seppanen, Marko (2009), "Empirical Classification of Resources in a Business Model Concept", Intangible Capital, C. 5, S. 2: 102-124.

Sevilengül, Orhan (2008), Genel Muhasebe, Ankara: Gazi Kitabevi.

Snell, Scott; Dean, James Jr. (1992), “Integrated Manufacturing and Human Resources Management: A Human Capital Perspective", Academy of Management Journal, C. 35, S. 3: 467-504.

Spanos, Yiannis; Lioukas, Spyros, (2001), “An Examination into the Causal Logic of Rent Generation: Contrasting Porter's Competitive Strategy Framework and Resource Based Perspective", Strategic Management Journal, C. 22, S. 10: 907-934.

Subramaniam, Mohan ve Youndt, Mark (2005), "The Influence of Intellectual Capital On The Types of Innovative Capabilities", Academy of Management Journal, C. 48 S. 3: 450-463.

Sveiby, Karl Erik (1997), The New Organizational Wealth-Managing and Measuring Knowledge-Based Assets, San Francisco: Berrett-Koehler Publishers.

Talberg, Magnus; Winge, Christian; Frydenberg, Stein; Westgaard, Sjur (2008), "Capital Structure Across Industries", International Journal of the Economics of Business, C. 15, S. 2: 181-200.

Teece, David; Pisano, Gary; Shuen, Amy (1997), “Dynamic Capabilities and Strategic Management", Strategic Management Journal, C. 18, S. 7: 509-533.

Terim, Burak; Kayalı, Cevdet Alptekin (2009), "Sermaye Yapısını Belirleyici Etmenler: Türkiye'de İmalat Sanayi Örneği", Celal Bayar Üniversitesi Sosyal Bilimler Dergisi, C. 7, S. 1: 125-154.

Tobb, (2019), "Eurostat Verilerine Göre Teknoloji Sınıflamaları", http://www.tobb.org.tr/SanayiMudurlugu/Documents/YerliMali/Eurostat\%20verilerine\%20gore\%20teknoloji\%20siniflamalari.docx ,(Erişim: 01.02.2019). 


\section{Eskişehir Osmangazi Üniversitesi IïB Dergisi}

Tokgöz, Nuray; Taşcı, Deniz; Koç, Umut; Türker, Yücel; Yalçınkaya, Akansel (2020), “Imalat Sektöründe Faaliyet Gösteren KOBi'lerde İnsan Kaynakları Yönetimi Uygulamalarının Belirleyicileri: Eskişehir Örneği”, Doğuş Üniversitesi Dergisi, C. 21, S. $1: 49-68$.

Tsai, Wenpin; Ghoshal, Sumantra (1998), "Social Capital and Value Creation: The Value of Intrafirm Networks", Academy of Management Journal, C. 41, S. 4: 464-476.

Walsh, Kate; Enz, Cathy A.; Canina, Linda (2008), "The Impact of Strategic Orientation on Intellectual Capital Investments in Customer Service Firms", Journal of Service Research, C. 10, S. 4: 300-317.

Wellalage, Nirosha Hewa; Locke, Stuart (2014), "Impact of Ownership Structure on Capital Structure of New Zealand Unlisted firms", Journal of Small Business and Enterprise Development, C. 22, S. 1: 127-142.

Wernerfelt, Birger (1984), “A Resource-Based View of the Firm”, Strategic Management Journal, C. 5, S. 2: 171-180.

Wernerfelt, Birger (1995), "The Resource-Based View of the Firm: Ten Years After", Strategic Management Journal, C. 16, S. 3: 171-174.

Whiting, Rosalind H.; Woodcock, James (2011), "Firm Characteristics and Intellectual Capital Disclosure by Australian Companies", Journal of Human Resource Costing \& Accounting, C. 15, S. 2: 102-126.

Yereli, Ayşe; Gerşil, Gülşen (2005), “Entelektüel Sermayeyi Ölçme ve Raporlama Yöntemleri”, Yönetim ve Ekonomi, C. 12, S.2: $17-29$.

Yıldız, Sebahattin (2011), "Entelektüel Sermayenin İşletme Performansına Etkisi: Bankacılık Sektöründe Bir Araştırma", Anadolu Üniversitesi Sosyal Bilimler Dergisi, C. 11, S. 3: 11-28.

Zahra, Shaker.; Covin, Jeffrey (1993), "Business Strategy, Technology Policy and Firm Performance", Strategic Management Journal, C. 14, S. 6: 451-478.

Zhang, Li; Liu, Yingqi; Kokko, Ari (2019), “Does Ownership Determine Business Model?”, Sustainability, C. 11, S. 11: 121. 


\section{Extended Summary}

\section{The Impact of Organizational Resources on Competitive Strategies within the Scope of Resource Based View: A Research in Top 1000 Industrial Enterprises of Turkey}

Resource based view asserts that sustainable competitive advantage derives from organizational capabilities and resources. Organizational resources can be classified as tangible and intangible resources. While the sum of current assets and fixed assets of an organization are used in determining the tangible resources, intellectual capital is used for the determination of intangible resources. Intellectual capital involves the people of a firm (human capital), the value of internal and external relationships of a firm (social capital), and everything that remains when employees return their home (structural capital). Besides, resource based view states that organizational resources is closely related to firms' business level strategy. Business level strategies are the most important part of the strategic management process during strategy formulation. Competitive strategies are specified as cost leadership strategy and differentiation strategy in the context of business level strategies. A firm implementing cost leadership strategy, offers standart products and services at lower costs. With cost leadership strategy, firms aim to increase efficiencies and reduce production costs below the industry average or their closest competitor. In case of differentiation strategy, firms seek to gain competitive advantage by producing differentiated products and services valued by customers unlike its competitors.

Although organizational resources are significant for firms while strategy selection, empirical studies which search the relationship between resources and strategy are still rare. Particularly, studies investigate the effect of organizational resources (total assets as tangible resources and intelectual capital as intangible resources) on cost leadership strategy and differentiation strategy are limited. Therefore, the main purpose of this research is to investigate the effects of organizational resources on competitive strategies within the framework of resource based view. In this direction, consistent with the literature, this research suggests that organizations' tangible resources predict the cost leadership strategy (Grant, 1991; Kaleka, 2002), whereas intangible resources (intellectual capital) affect the differentiation strategy (Walsh, 2008; Adedoyin ve Ezenwakelu, 2019). It is also examined whether firms differ in terms of organizational resources and competitive strategies according to technological classification of the industry and the ownership structure.

Research has been conducted with the first 1000 major industrial firms of Turkey (Turkey's top 500 industrial enterprises and Turkey's second top 500 industrial enterprises). Those firms determined as population of this research and data obtained from those firms by full counting method. In the data collection process, a firm information form, the intellectual capital scale (Subramaniam \& Youndt, 2005) and the competitive strategy scale (Parnell, 2011) have been used. Exploratory factor analysis has been applied to determine the factor structures of the intellectual capital scale and the competitive strategy scale. The intellectual capital scale is split into three factors in accordance with the literature. It has a KMO value of ,85; and Barletts' test value $(X 2=1166,008)$ is significant $(p<0,001)$. The three factors explain $58,72 \%$ of the total variance. Cronbachs' alpha coefficient for the reliability of scale is, 86 . The competitive strategy scale is gathered under two factors as remarked through the literature. The KMO value for the scale is ,797; and Barletts' test value $(X 2=936,552)$ is significant $(p<0,001)$. The two factors explain $50,12 \%$ of the total variance. Cronbachs' alpha coefficient for the scale is, 816 , which shows it to be a reliable measurement tool. In the following process to reveal findings, correlation analyses, regression analyses, one way analysis of variance (ANOVA) and Tukey's test (to find the difference between each pair of group means) carried out.

The findings of the regression analysis showed that tangible resources of the organization have no significant effect $(p>0,05)$ on the cost leadership strategy. Besides, it has been observed that the only structural capital dimension of intangible resources affect the differentiation strategy (beta $=, 349 ; p<0,001$ ). ANOVA analysis demonstrated that firms' social capital varies up to firms' ownership structure $(p<0,05)$. The Tukey test indicated that firms are both domestic and foreign owned $(\bar{x}: 6,00)$ have more social capital than firms are completely domestic owned $(\bar{x}: 5,65)$. Furthermore, differentiation strategy and social capital of firms differed significantly $(p<0,05)$ with regards to technological classification of the industry. Tukey test revealed that medium-high technology industry firms $(\bar{x}: 5,89)$ have more social capital than medium-low technology industry firms $(\bar{x}: 5,51)$ and low technology industry firms refer more differentiation strategy $(\bar{x}: 4,27)$ than medium-low technology industry firms $(\bar{x}: 3,92)$.

This research contributes to the literature within the perspective of resource based view. Resources have important role in the strategy formulation process is the expectation of resource based theory and findings of this research is consistent with that expectation. On the other hand, there is one another approach that asserts competitive strategies are also affected by external factors (Porter, 1980). However, external factors are not evaluated in the scope of this research. Only one side of coin (Wernerfelt, 1984) is focused. Hence, this is an important limitation for this research. 


\section{Eskişehir Osmangazi Üniversitesi IïB Dergisi}

Moreover, one another important limitation is that the sample of this research consists of large scale companies operating in the manufacturing industry. Therefore, future studies also will be conducted on different samples and create more explanatory models considering external factors. Besides, it is suggested that the effects of organizational resources on different types of competitive strategies will be examined since there are some other classifications on competitive strategies. 